\title{
İş Stresi ve Pozitif Psikolojik Sermayenin Tükenmişlik Üzerine Etkisi: Bankacılık Sektöründe Bir Araştırma
}

\author{
EBRU BEYZA BAYARÇELIK* \\ ebbayarcelik@gelisim.edu.tr \\ ORCID ID: 0000-0003-4886-5719
}

\author{
BURÇAK VATANSEVER DURMAZ** \\ burcak.vatansever@gss.bau.edu.tr \\ ORCID ID: 0000-0001-8940-0761
}

EBRU NILAY GÜRLER ${ }^{* * *}$
nilay_gurler@hotmail.com
ORCID ID: 0000-0002-0682-441x

Öz: Teknolojik gelişmeler ve yoğun rekabet tüm sektörlede hissedilen iş stresini artırarak, duygusal kaynakları azaltmış ve bunların sonucunda tükenmişlik daha sık ortaya çıkmaya başlamıştır. Banka çalışanları arasında çok yaygın hissedilen tükenmişliğe karşın, tükenmişlikle mücadele için pozitif kaynakların etkilerini araştıran çok az sayıda çalışma bulunmaktadır. Bu çalışmanın amacı bankacılık sektöründe çalışanların hissettiği işstresi ve psikolojik sermayenin tükenmişlik üzerindeki etkisini irdelemektedir. Çalışmanın örneklemini İstanbul ilinde faaliyet gösteren 300 kamu ve özel banka çalışanları oluşmaktadır. Veri toplama araçları olarak Işs Stresi Ölçeği, Psikolojik Sermaye Ölçeği ve Maslach Tükenmişlik Envanteri kullanılmıştır. Yapılan analiz sonuçlarına göre banka çalışanlarının iş stres düzeyleri tükenmişliğin iki alt boyutu olan duygusal tükenme ve duyarsızlaşma düzeyini arttırırken, çalışanların pozitif psikolojik sermaye düzeyleri sadece duygusal tükenme düzeyini azalttığı, duyarsızlaşmayı etkilemediğ $i$ görülmüştür.

Anahtar kelimeler: İşstresi, Pozitif psikolojik sermaye, Tükenmişlik, Bankacılık sektörü..

\section{Giriş}

Hızla globalleşen günümüz dünyasında, rekabetin en üst seviyelerde yaşandığı ve teknolojik gelişimlerin çok hızlı gerçekleştiği çalışma hayatında, insan kaynağı önemli bir faktörü temsil etmektedir. Hizmet sektöründeki örgütler ne kadar maddesel unsurlara sahip olsalar da, faaliyetlerini devam ettirebilmeleri için insan kaynaklarına büyük ölçüde ihtiyaç duymaktadırlar. Özellikle son yıllarda küresel ve yerel ekonomik daralmaların etkisiyle bankacılık sektöründe yüksek satış hedefleri,

\footnotetext{
* Dr. Öğr. Üyesi, İstanbul Gelişim Üniversitesi, İktisadi İdari ve Sosyal Bilimler Fakültesi.

** Dr. Öğretim Üyesi, Bahçeşehir Üniversitesi, Meslek Yüksek Okulu.

*** Bahçeşehir Üniversitesi, Yüksek Lisans Öğrencisi.
} 
bankaların karlılığını artırmak adına kritik öneme sahip olmaya başlamıştır. Küresel satın almalar ve teknolojik değişimler, bankaların fiziksel çalışma ortamlarını değiştirmeye başlamış, işlemlerini sanal ortamlara taşımaya ve küçülmeye neden olmuştur. Bankacılık sektöründe yaşanan bu köklü değişimler, araştırmacıları banka çalışanlarında yaşanan yoğun strese ve buna bağlı oluşan tükenmişlik duygusunu araştırmaya yönlendirmiştir.

Tükenmişlik, duygusal ve kişilerarası strese verilen, bireysel tepkilerden oluşan, özellikle bireyde yoğun iş stresi sonucu ortaya çıkan, duygusal ve davranışsal alanda yaşanan problemler bütünüdür. ${ }^{1}$ Tükenmişliğin en önemli önceli iş stresidir. İş stresi, iş yerinde strese neden olabilecek çalışma ortamı, diğer çalışanlar ile etkileşimi, yapılan işin niteliği gibi çalışanda oluşabilecek kaygı, endişe ve gerilim halidir. ${ }^{2}$ İş stresi, çalışanlarda bireysel ve örgütsel açıdan olumsuz sonuçlar doğrumaktadır. Stres hisseden birey fiziksel, davranışsal ve psikolojik olumsuz sonuçlarla karşılaşırken, örgütsel olarak işe geç gitme, devamsızlık, verimsizlik, işe gelmeme ve işten ayrılma gibi örgütsel sonuçlara neden olarak, genel iş etkinliğini ve işleyişi olumsuz yönde etkilediği görülmektedir. İş stresi ve tükenmişlik arasında yapılan araştırmalarda bankalar gibi müşterisiyle yüzyüze iletişimin olduğu, öğretmenler, ${ }^{3}$ polisler, ${ }^{4}$ sağlık personeli ${ }^{5}$ hemşireler ${ }^{6}$ gibi farklı meslek gruplarında da iş stresi ile tükenmişlik arasında anlamlı ve pozitif ilişki olduğu saptanmıştır.

1990’ların başında geliştirilen Kaynakların Korunma Teorisi, örgüt içinde gelişen stres ve tükenmişlik sürecini anlamayı amaçlamıştır. Kaynakların Korunma Teorisinin temel prensibi bireylerin kaynaklarının niteliğini ve miktarını yaratma, destekleme, saklama ve koruma konusunda doğuştan gelen ve aynı zamanda öğrenilmiş bir güce sahip olmalarıdır. ${ }^{7}$ Pek çok şey kaynak olarak algılanabilir, ancak KKT teorisi için önemli olan bireyin refahını ve hayatını devam ettirmesine yardımcı olan temel kaynaklar (örneğin, sağlık, aile, barınacak yer, önemi kişlere bağlılık, özsaygı) veya temel kaynakları yaratma ve sürdürme süreciyle bağlantılı olan kaynaklardır (örneğin, para, krediler). Kaynakların Korunma teorisine göre stres, (1) bireylerin kay-

$1^{\star}$ Dr. Öğr. Üyesi, İstanbul Gelişim Üniversitesi

** Dr. Öğretim Üyesi, Bahçeşehir Üniversitesi, Meslek Yüksek Okulu Yönetim Organizasyon Anabilim Dalı

*** Bahçeşehir Üniversitesi, Yüksek Lisans Öğrencisi.

Reyhan Ersezgin ve Emine Sevinç Sevi Tok, "Algılanan İş Stresi, Psikolojik Dayanıklılık, Başa Çıkma Stilleri Ve

Öz-Duyarlılığın Tükenmişlik Düzeyini Yordayıcı Etkisi”, Uludağ Üniversitesi Fen-Edebiyat Fakültesi Sosyal Bilimler Dergisi, 20/36 (2019).

2 Tom Cox,. Stress Research and Stress Management: Putting Theory To Work. Sudbury: Hse Books, 1993.

3 Lulu Zhang, Jingping Zhao, Huaqing Xiao, Hongbo Zheng, Yaonan Xiao, Miaoyang Chen ve Dingling Chen, "Mental Health And Burnout in Primary And Secondary School Teachers in The Remote Mountain Areas Of Guangdong Province in The People's Republic Of China", Neuropsychiatric disease and treatment, 10 (2014), s.123. 4 Patrik Manzoni ve Manuel Eisner, "Violence Between The Police And The Public: Influences Of Work-Related Stress, Job Satisfaction, Burnout, And Situational Factors”, Criminal Justice and Behavior, 33/5 (2006).

5 Young-Hee Yom, "Analysis of Burnout and Job Satisfaction Among Nurses Based on the Job Demand-Resource Model”, J. Korean Acad. Nurs, 43 (2013).

6 Hee-YunYim RN, Hyun-JuSeo RN, Yoonhyung Cho, Jin Hee Kim RN, “Mediating Role of Psychological Capital in Relationship Between Occupational Stress and Turnover Intention Among Nurses At Veterans Administration Hospitals in Korea”, Asian Nursing Research,11/1 (2017).

7 Stevan E. Hobfoll, "The Influence of Culture, Community, and The Nested-Self in the Stress Process: Advancing Conservation of Resources Theory”, Applied psychology, 50/3 (2001). 
nakları kaybedileceği ile tehdit edildiğinde,(2) kaynakların gerçekten kaybolduğunda veya (3) bireylerin eldeki kaynakların harcanmasına rağmen yeterli kaynağın elde edilememesi durumunda meydana gelir. Tükenmişlik ise böyle bir stres sonucudur ve tipik olarak, kaynak kazancını veya yenilenmesini dengelemeksizin, kaynakların yavaş yavaş kaybedilmesi sürecinden kaynaklanır. ${ }^{8}$ Teori, bireylerin stresle karşı karşıya kaldıklarında kaynak kaybını minimize etmeye çalışarak bu duruma tepki gösterdiğini savunmaktadır. Bu teorinin diğer stres teorilerinden en temel farkı mevcut durumda herhangi bir stresör olmaması halinde birey, gelecekte ortaya çıkabilecek bir kaynak kabına karşı mevcut kaynaklarını artırmaya çalışmaktadır. ${ }^{9}$ Bu bağlamda Kaynakları Koruma teorisine göre çok kaynağa sahip bireylerin kaynak kaybına karşı daha dayanıklı, buna karşın az kaynağa sahip olanların ise daha dayanıksız olacağ 1 vurgulanmaktadır. ${ }^{10}$

Dünyada ve ülkemizde yaşanan sosyal ve ekonomik değişimler, bilim insanlarını günlük hayatta bireylerin sıklıkla karşılaştıkları iş stresi ile tükenmişlik duygularından kendilerini nasıl koruyabilecekleri, nasıl başa edebilecekleri gibi konularda araştırmalar yapmaya yönlendirmiştir. ${ }^{11}$ Pozitif psikolojik sermaye "pozitif psikoloji" kapsamında gelişen kavramlardan birisidir. Çalışanların örgüt içerisinde mutlu ve huzurlu çalışmalarını amaçlayarak, özellikle çalışanların örgüt içerisinde olumlu davranışlarının gelişimini destekleyici unsurları araştırmıştır. Pozitif psikolojik sermaye "ümit”, "iyimserlik", "psikolojik dayanıklılı" ve "öz-yeterlilik” alt boyutlarından oluşmaktadır ve bireyin sahip olduğu olumlu özellikler bütünü olarak tanımlanırken, kişilik özelliklerinden farklı olarak gelişime açık olduğu vurgulanmaktadır. ${ }^{12}$ Psikolojik sermayesi yüksek olan çalışanlar, iş hayatında neleri yapıp neleri yapamayacaklarınına dair inançları yüksek olan, yaşadıkları zorluk ve sıkıntılara rağmen kendilerini, negatif durumdan hızlıca çıkarıp toparlanabilen, hedef ve amaçlarına odaklanıp, yollarına devam edebilen, yeri geldiğinde kendi kendini motive edebilen bireylerdir. Yüksek pozitif pskilojik sermayeye sahip olan bireylerin iş tatmini, örgütsel bağlılık, iş performansı, örgütsel vatandaşlık gibi olumlu çıktılarının yüksek; stres, tükenmişik ve işten ayrılma niyeti gibi olmusuz çıktılarının daha düşük olduğu bilinmektedir. ${ }^{13}$ Bu bağlamda pozitif psikolojik sermayesi yüksek olan kişilerin, pozitif duygularının fazla olması, çalışanların yoğun çalışma temposu, yüksek hedefler, beklentiler ve çalışma düzeni içindeki olumsuzlardan daha düşük seviyede

8 Gorgievski, Marjan J., ve Stevan E. Hobfoll, "Work Can Burn Us Out or Fire Us Up: Conservation of Resources in Burnout and Engagement", Handbook of Stress And Burnout in Health Care (2008).

9 Senay Yürür, "Öğrenilmiş Güçlülük, Kıdem ve Medeni Durumun Duygusal Tükenmedeki Rolü: Kaynakların Korunması Teorisi Kapsamında Bir Analiz”, Atatürk Üniversitesi İktisadi ve İdari Bilimler Dergisi, 25/1 (2011), s.110.

10 Stevan E. Hobfoll, "The Influence of Culture, Community, and The Nested-Self in The Stress Process: Advancing Conservation of Resources Theory", Applied psychology, 50/3 (2001).

11 Ersezgin ve Sevi Tok, "Algılanan İş Stresi, Psikolojik Dayanıklılık, Başa Çıkma Stilleri Ve Öz-Duyarlılığın Tükenmişlik Düzeyini Yordayıcı Etkisi”, s.4.

12 Ahmet Erkuş ve Mine Afacan Fındıklı, "Psikolojik Sermayenin İş Tatmini, İş Performansı ve İşten Ayrılma Niyeti Üzerindeki Etkisine Yönelik Bir Araştırma", Istanbul University Journal of the School of Business Administration, 42/2 (2013).

13 Hilmiye Tetik, Türesin, Lale Oral Ataç, and Sevinç Köse, "Psikolojik Sermaye İle İş Doyumu ve Performans İlişkisi: Türkiyede Yapılan Araştırmalar Üzerinden Bir Meta Analizi”, Atatürk Üniversitesi İktisadi ve İdari Bilimler Dergisi, 32/2 (2018). 
etkilenmelerini sağlayacaktır. Bütün bu bilgilerin ışığında, bu araştırmanın amacı, iş stresi ve pozitif psikolojik sermayenin hizmet sektöründeki banka çalışanlarının tükenmişlikleri üzerine etkilerini araştırmaktır. Yerli ve yabancı yazında iş stresi ve pozitif psikolojik sermayenin tükenmişlik üzerine etkilerinin incelendiği araştırmalar olmasına karşın bankacılık sektöründe bu değişkenlerin birlikte model olarak ele alındığı nadir çalışma bulunmaktadır. Bu çalışma ile Türkiye'deki bankacılık sektöründe çok nadir irdelenen, iş stresi ve pozitif psikolojik sermaye'nin ve tükenmişlik üzerine etkileri incelenerek bankacılık sektörü ilişkin bulgular ortaya koyularak literatüredeki bu konudaki boşluk doldurulmaya çalışılacaktır.

\section{İş Stresi}

İş stresinin ilk derinlemesine çalışması, 1960’ların başında Michigan Sosyal Araştırma Enstitüsü tarafından yürütülmüştür. Bu çalışmada, iş yerinde strese neden olabilecek olumsuz iş ortamına, olaylara ve psikososyal faktörlere odaklanılmıştır. Günümüzde bireyler zamanının çoğunu çalıştıkları örgütlerde geçirmektedirler ve görevlerini yerine getirirken yaşadıkları olumsuz durumlar sonucu iş stresi oluşmaktadır bu yüzden de stres daha çok iş stresi olarak karşımıza çıkmaktadır. İş stresi, işgörenlerin ve yöneticilerin çalışma ortamlarında karşılaştıkları etkilere yönelik fiziksel, psikolojik ve davranışsal durumlarını göstermektedir. Ayrıc iş stresi, işgörenlerin fizyolojik ve psikolojik sağlıklarını etkilemekle kalmayıp, verimliliğin düşmesine, hatta üretkenliğin azalmasına neden olan ve örgüte ekonomik zorluklar yaşatan bir konudur.

Stres olgusu olumlu ve olumsuz olarak iki şekilde açıklanmaktadır. Stres, adından dolayı her zaman olumsuz olarak algılansa da motivasyon faktörü olarak kullanılarak çalışanları pozitif yönde etkileyen hatta zaman zaman düşük seviyelerde gerekli görülen faktörlerdendir. Olumlu stres, bireyi endişe yerine, çalışma esnasında verimli olmaya iten, kişiye yaşam ve çalışma isteği veren ve motive eden stresin adıdır. K1saca, olumlu stres işgörenlerin, yaptıkları işe daha iyi konsantre olmalarını ve daha verimli çalışmalarını sağlamaktadır. Olumsuz stres ise olumlu stresin verdiği özelliklerin tam tersi olarak, kişiye yaşama sevinci vermeyen, kişiye çaresizlik, yetersizlik ve en önemlisi de güvenini kaybetmesine neden olan strestir. Olumsuz stres psikolojik olarak tedirginlik, endişe, hüzün, depresyon, karamsarlık, umursamazlık, özsaygı eksikliği, çabuk sinirleme, bitkinlik, az uyuma, sigara ve alkol tüketiminde artış sonuçlarını doğururken, fizyolojik olarak atardamar kan basıncında sürekli yükselme, sindirim güçlüğü, kilo alma veya verme şeklinde sonuçlar doğurmaktadır. ${ }^{14}$

Eren’e göre bireyin kendisinden doğan stres kaynakları daha çok bireyin fizyolojik ve psikolojik sorunlarıyla ilgilidir. ${ }^{15}$ Bireysel etkilerin başında kişisel, duygusal, ekonomik ve ailevi problemler gelmektedir. Çalışanların duygusal açıdan hassas ve zayıf olmaları, içe dönük kişilik özellikleri, rekabetçi ve mücadeleci olmamaları, strese neden olabilecek diğer bireysel özelliklerdir. ${ }^{16}$ Bireyin kişilik özelliklerinden kaynaklanabilecek stres unsurları bireyin çalışırken yanlışa iten dürtüler, bir işi yaparken

14 Hasan Özgür Özen, "Üniversite ve Devlet Hastanelerinde Çalışan Hemşirelerin Stres Düzeylerinin Karşılaştırılması: Zonguldak Örneği”. Doktora Tezi, Zonguldak Karaelmas Üniversitesi, 2011.

15 Erol Eren, Örgütsel Davranışve Yönetim Psikolojisi, İstanbul: Beta Basım Yayım Dağıtım, 2014.

16 İnayet Pehlivan Aydın, İş Yaşamında Stres. İstanbul: Pegem A Yayıncılık, 2008. 
aceleci davranmak, her şeyi mükemmel yapma isteği, insanları memnun edememe korkusu, yoğun çalışma temposu, herkesten güçlü olma isteği, ulaşılması zor imkanlara ulaşma isteği, işten çıkarılma korkusu ve işte gereğinden fazla sorumluluk yüklenmesi olarak sıralanabilir. Strese neden olan bir başka etken ise yaş ve cinsiyettir. Yaşa bağlı sorunlar genellikle yaşın ilerlediği orta yaşlar ve yaşlılıktaki dönemlerde yoğunlaşmaktadır. Bu dönemlerde görülen fiziksel ve zihinsel değişiklikler duygusal ve ruhsal sorunlar, hayal kırıklıkları insanlarda belirgin ölçüde stres oluşumuna neden olmaktadır. ${ }^{17}$ Cinsiyet bakımında, kadınların hem iş hem de aile hayatını beraber devam etmeleri sebebiyle hissettikleri stres seviyesi erkeklere oranla daha fazladır. Ayrıca, kadınların ve erkekelerin biyolojik farklılıklarından dolayı stresle başa çıkma yollarıda farklılaşmaktadır. Erkeklerin stresle başa çıkabilme dayanıklılığı kadınlara göre daha azdır. ${ }^{18}$ Bununla birlikte aile içinde yaşanan hastalık, ölüm, boşanma ve ekonomik sorunlar da stresi ortaya çıkaran önemli konular olarak ele alınmaktadır. Aile içi ilişkilerde yaşanan stres kaynakları da bireyin sosyal ve çalışma hayatını olumsuz olarak etkilemektedir. ${ }^{19}$ Bireylerin belirli bir gelir kaynağından mahrum kalması anlamına gelen işsizlikte strese neden olan diğer bir durumdur. İşsizlik, bireyin temel ihtiyaçlarını karşılamasında güçlükler doğuracağı gibi ekonomik açıdan da zorluklar çekmesine sebep olacaktır. Bu da ekonomik açıdan en önemli stres kaynağı olarak gösterilmektedir. ${ }^{20}$

Örgütsel stres, kişi ve iş ilişkilerinden doğan, insanı normal işlevlerinden alıkoyan değişiklikler getiren bir durumdur. ${ }^{21}$ Bu kavram Cooper-Marshall tarafindan mesleki stres (occupational stress), War-Wall tarafından çalışma stresi (workstress), Buzzard tarafından endüstriyel stres (industrielstress), Caplan-Cobb-French tarafindan iş stresi (jobstress), Buck tarafından iş baskısı (jobpressure) ve Singer tarafından işgerilimi (jobstrain) şeklinde ifade edilmektedir. ${ }^{22}$ Çalışanın fiziksel ve psikolojik yapısı, etkilenen stres düzeyi ve yapılacak işin niteliği gibi faktörler örgütsel stresi etkilemektedir. Bu faktörlerin hepsi örgütlerin performansını, verimliliğini, çalışanın motivasyonunu ve üretilen malın kalitesini olumsuz yönde etkilemektedir. ${ }^{23}$

Stres faktörü açısından, çalışma hayatındaki bireyler arasındaki ilişkiler, iletişim ve etkileşimler son derece önemlidir. İşyeri ilişkilerini düzgün şekilde düzenleyemeyen kişiler, kendilerini ve diğer çalışanları negatif olarak etkilemekte, örgütsel ilişkilerden kaynaklanan stresi yaşayabilmektedirler. ${ }^{24}$ Doğru kararlar vermek, iş verimliliğini

17 Göknur Ersarı, Atılhan Naktıyok, "İş Görenin İçsel ve Dışsal Motivasyonunda Stresle Mücadele Tekniklerinin Rolü”, Atatürk Üniversitesi Sosyal Bilimler Enstitüsü Dergisi, (2012). Salih. Güney, "Stres ve Stresle Başa Çıkma”. Yönetim ve Organizasyon, Ed. Salih Güney, Ankara: Nobel Yayınevi, 2001.

18 Güney, Stres ve Stresle Başa Çıkma, s.433.

19 Hasan Ekinci, Süleyman Ekici, "Yöneticiler Üzerindeki Etkileri Açısından Stres Kaynakları ve Bir Uygulama”, Uludağ Üniversitesi II BF Dergisi, 22/2 (2003).

20 Eren, Örgütsel Davranış ve Yönetim Psikolojisi, s.300.

21 Sevgül Akgündüz, "Örgütsel Stres Kaynaklarının Çalışanların İş Tatmini Üzerindeki Etkisi ve Banka Çalışanları Iç̧in Yapılan Bir Araştırma”, Doktora Tezi, DEÜ, 2006.

22 Özlem Güllüoğlu, "Yerel Televizyon Çalışanlarının Örgütsel Stres Faktörleri: Kayseri İlinde Bir Araştırma", İstanbul Üniversitesi İletişim Fakültesi Dergisi| Istanbul University Faculty of Communication Journal, 43 (2012), s.79.

23 Bircan Sefa, "Beyoğlu Kamu Hastaneleri Birliğine Bağlı Hastanelerin Acil Servis Çalışanlarının Karşılaştığı Risk ve Tehlikelerin İ ş Stresine Etkisi”, Yüksek Lisans Tezi, Okan Üniversitesi, 2016.

24 Asım Saldamlı, "Otel İşletmelerinde Stres Kaynakları ve Çalışanlar Üzerindeki Etkileri: Beş Yıldızlı Otellerde 
sağlamak, etkin ve adil bir çalışma ortamı sağlamak ve kurum içi stresi azaltmak için, örgütsel ilişkilere önem verilmelidir. Bu doğrultuda örgütte yaşanan stresin sebepleri olarak genellikle yönetim biçimindeki örgütsel eksiklikler ve adalet algısı, bireyin işini kaybetme korkusu, örgütün amaç ve hedeflerinin tam olarak belli olmaması ve çalışanlara aktarılmaması, performans değerlendirmelerinin yanlış, eksik ve adaletsiz yapılması, ücret ve terfi sayılabilir. ${ }^{25}$ Yüksek düzeyde yaşanan stres, çalışanlarda performans düşmesine sebep olmaktadır. ${ }^{26} \mathrm{Bu}$ yüzden, örgütsel hedefler doğrultusunda en önemli faktör moraldir. Örgütte çalışmakta olan bireylerin örgüt içindeki rolüne verilen değer tatmin edici değilse, bireyde moral eksikliği ve sonucunda da kişide motivasyon kaybı ve kötü performans göstermesine neden olacaktır. ${ }^{27}$

\section{Pozitif Psikolojik Sermaye}

Finans alanındaki geleneksel kullanımı dışındaki "sermaye" kelimesi, yönetim yazınında insan sermayesi, sosyal sermaye, örgüt ve ilişkisel sermayler olarak kavramlaştırılmıştır. Her geçen gün sosyal, beşeri, kültürel ve psikolojik sermaye gibi yeni sermaye biçimleri önemini arttırmaktadır. Hesaplanması nispeten zor ve belirsiz olan yeni sermayelerin firma değerine yatsınamayacak katkıları olduğu anlaşılmaktadır. Pozitif psikolojik sermaye örgütsel davranış yazınına 2000'li yıllardan sonra girmiştir ve psikoloji biliminin sadece olumsuz davranışları, sıkıntıları inceleyen yapısına tepki olarak bireylerin güçlü taraflarını ön plana çıkarmaya çalışan ve bu davranışların geliştirebilir olduğunu savunan bir akımdır. ${ }^{28}$ Örgütler için pozitif psikolojik sermaye ölçmesi zor olmasına karşın önemi oldukça fazladır. Luthans ve arkadaşlarının ${ }^{29}$ teorik modelle incelediği sermaye çeşitleri "neye sahipsin (geleneksel finansal-ekonomik sermaye)", "ne biliyorsun (beşeri sermaye)", "kimi tanıyorsun (sosyal sermaye)", "kimsin (pozitif psikolojik sermaye)" sorularıyla birbirinden ayrilmaktadır. ${ }^{30}$

Pozitif psikolojik sermayeyi ilk tanımlayan Seligman (1998) göre, psikoloji bilimi bireylerin bozulmuş, karanlık, normalin dışındaki yönleri yerine; bireylerin güçlü, pozitif yönlerinin ve yetenkelerinin bellirlenmesine odaklanmalıdır, böylece çalışanların nasıl daha mutlu, huzurlu, başarılı ve kendini geliştirebilen bireylere dönüştürülülebileciğini ifade etmiştir. ${ }^{31}$ Birleşik bir üst yapı olarak nitelendirilen pozitif psikolojik sermaye, bireyin pozitif psikolojik gelişme hali olarak tanımlanmakta ve zorlu durumlarda başarı sağlayabilmek için yeterli çabada bulunma(öz-yeterlilik), gelecekte başarılı olacağına dair pozitif düşünceler(iyimserlik), hedeflere ulaşabilmek için bütün yolları arama(umut), yaşanan sorunlar karşısında dayanıklı olma(-

Bir Uygulama”, Çukurova Üniversitesi Sosyal Bilimler Enstitüsü Dergisi, 6/6 (2000).

25 Hasan Tutar, İs Yerinde Psikolojik Siddet. Ankara: Platin, Barıș Kitap Basım Yayın Dagǐtım Ltd Şti, 2004.

26 Alper Erturk, Daniel J. Inman, Piezoelectric Energy Harvesting. John Wiley \& Sons, 2011, s.400.

27 Enver Özkalp ve Çiğdem Kırel. Örgütsel Davranış, Bursa: Ekin Yayınevi, 2010, s.82.

28 Fred Luthans; Kyle W Luthans, Brett C Luthans, Positive Psychological Capital: Beyond Human and Social Capital, 2004.

29 Luthans vd.,Business Horizons.

30 Luthans vd.,Business Horizons.

31 Csikszentmihalyi, Mihaly ve Martin E. Seligman, "Positive Psychology: An Introduction", American Psychologist, 55/1 (2000). 
dayanıklılık) olarak dört ana unsurdan oluşmaktadır. ${ }^{32}$ Luthans ve arkadaşları, pozitif psikolojik sermayenin kişilik özelliklerinden farklı olarak, dört boyutun bir araya gelerek bütüncül bir yapıya sahip olduğunu özellikle belirtmektedir, bu bağlamda poztif psikolojik sermaye, alt boyutlarının birbiriyle etkileşimi sonucunda ortaya çkan özellikler bütünü olduğu altı çizilerek vurgulanmıştır. ${ }^{33}$

Pozitif psikolojik sermayeyinin ilk unsuru olan öz yeterlilik, çalışanların belli sonuçlara ulaşmak için bilişsel kaynakları kullanma yeteneğine duyduğu inanç olarak tanımlanmaktadır. Bireylerin kendi kendini motive edebilme, harekete geçebilme inançlarıdır. Çalışanların öz-yeterlik düzeyleri artıkça kendine olan güveni ve inanc1 daha da güçlü olacaktır. ${ }^{34}$ Bireylerin kendi kendilerine yetebilme durumlarında, o kişinin sosyal ve ailevi sorunları acısından önemlidir. Bireyler, kendilerine zaman ayırıp sosyal aktiviteler gerçekleştiremiyorlarsa bu onları psikolojik olarak sıkıntıya sokacak ve onların strese girmelerine neden olacaktır. Strese giren bireylerde kendilerini bitmiş, tükenmiş ve yorgun hissedeceklerdir. Kendilerini tükenmiş hisseden bireyler, güçsüzdürler ve kendi kendilerine yetebilme konusunda zorluk yaşayacaklardır. Umut, amaçlara ulaşmada çaba ve azim göstererek, hedefi gerçekleştirmek için alternatif yollardan türetilen olumlu bir motivasyon durumu olarak tanımlanır. Bireyin hedefe ulaşmadaki yüksek umud düzeyi, kendisinde olumlu duyguların daha fazla hissederek çabayı artırmaktadır. İyimserlik, bireyin olayları yorumlama biçimine bağlıdır. İyimserlik, bireylerin iyi ve olumlu olayları içsel, kalıcı nedenlerle ilişkilendirmesiyken, kötü ve olumsuz olayları dışsal ve geçici nedenlerle ilişkilendirmesi olarak tanımlanmaktadır. İyimserlik, bireylerin yaşadıkları olumlu olaylar karşısında kendilerine pay çıkarmalarını, moral ve iş tatminlerini artırmlarını sağlarken, stres, depresyon, umutsuzluk ve kendini suçlama gibi olumsuz durumlarla baş edebilme ve uzak kalma imkanı sağlamaktadır. ${ }^{35}$ Pozitif psikolojinin son boyutu Psikolojik dayanıklılık, sıkıntı, başarısızlık hatta çok büyük pozitif değişimler ile başa çıkabilecek kapasiteye sahip olma olarak açıklanmaktadır. ${ }^{36}$ Dayanıklılı̆̆ın zorluklarla beslenen bir kişilik özelliği olmasından dolayı, son yıllarda bu kavrama verilen önem giderek artmaktadır. ${ }^{37}$ Bireyin dayanıklılık gösterdiği durum, yaşadığı zorluklara göre şekil alır; diğer bir deyişle bireyin dayanıklılık göstermesi için kötü durumlarla karşılaşmas1 gerekmektedir. Dayanıklılık sanılanın aksine pek çok bireyde bulunmakta, patolojiye değil sağlığa işaret etmekte ve gecikmiş acılara sebep olmamaktadır. ${ }^{38}$ Çalışma yaşamında dayanıklılık düzeyini artırmak ve çalışma ortamındaki zorluklarla

32 Luthans vd., Psychological Capital, s.3.

33 Fred Luthans, Youssef M. Carolyn ve Bruce J. Avolio, Psychological Capital: Developing the Human Competitive, New York: Edge, 2007. Fred Luthans, Bruce J. Avolio, James B. Avey, Steven M. Norman, "Psychological Capital: Measurement and Relationship with Performance and Job Satisfaction", Personnel Psychology, 60/3 (2007). Erkuş ve Afacan Fındıklı. "Psikolojik Sermayenin İş Tatmini, İş Performansı ve İşten Ayrılma Niyeti Üzerindeki Etkisine Yönelik Bir Araştırma”.

34 Enver Özkalp, “Örgütsel Davranışta Yeni Bir Boyut: Pozitif (Olumlu) Örgütsel Davranış Yaklaşımı ve Konuları”(17. Ulusal Yönetim ve Organizasyon Kongresi Bildiriler Kitabı, 2009).

35 Luthans, Youssef ve Avolio, Psychological Capital: Developing the Human Competitive Edge, s.15.

36 Luthans, Youssef ve Avolio, Psychological Capital: Developing the Human Competitive Edge, s.153.

37 Glenn E. Richardson, “The Metatheory of Resilience and Resiliency”, Journal of Clinical Psychology, 58/3 (2002), s.307.

38 George A. Bonanno, "Loss, Trauma, and Human Resilience: Have We Underestimated The Human Capacity to Thrive After Extremely Aversive Events? “, American psychologist, 59/1 (2004), s.20. 
başa çıkabilmek için çeşitli stratejiler önerilmektedir. Bunlardan ilki, çalışma ortamında profesyonel ilişki ve ağların kurulmasıdır. Bireyin ihtiyaç duyduğu anda yardımına koşabilecek ve sosyal destek sağlayabilecek arkadaşlarına sahip olması, risk faktörlerini azaltacaktır. Olumlu düşünmenin teşvik edilip sürdürülmesi, bir diğer stratejidir. Böylece, zorlukların da olumlu yanlarının olduğunun kabulünün ve zorluklarla mücadele ederken dahi umutlu ve iyimser olmanın teşvik edildiği bir çalışma ortamı sağlamaktadır. Bireylerin duygusal zekâlarının farkına varmalarının ve bunu geliştirmelerinin sağlanması, stres ve zorluklarla baş ederken duyguları anlayabilmelerini sağlar ve sorunların çözümünü kolaylaştırır. İş ve yaşam dengesinin sağlanması ve bireyin profesyonel hayatı dışında hayatına anlam katan inanç ve uğraşlarının olması, dayanıklılık açısından çok önemlidir. Edinilen deneyimlerden kazanç sağlama ve bunları izleyen deneyimlerde kullanabilme yeteneği de önemli bir faktördür. Bu yeteneğin kazandırılması için, yaşanan deneyimlerin kaleme alınması etkili bir yöntem olabilir. ${ }^{39}$

\section{Tükenmişlik}

Tükenmişlik tanımı ilk kez Freudenberger tarafından, 1974 yılında yapılmıştır. Bu tanımda çalışanlar arasında olan yorgunluk, hayal kırıklığı, işten atılma ve işi bırakma gibi evrelerden bahsetmiştir. Freudenbergere göre zamanla kötüye giden davranışların, insanların duygusal olarak acı çekmesine neden olduğunu ve psikolojik olarak olumsuz etkilediği öne sürülmüştür. ${ }^{40}$ Maslach $^{41}$ tükenmişlik evresini "İşi gereği yoğun duygusal taleplere maruz kalan ve sürekli diğer insanlarla yüz yüze çalışmak durumunda olan kişilerde görülen fiziksel bitkinlik, uzun süreli yorgunluk, çaresizlik, umutsuzluk, duygularının yapılan işe, hayata ve diğer insanlara karşı olumsuz tutumlarla yansıtılması ile oluşan bir sendrom" şeklinde tanımlamıştır. ${ }^{42}$ Tükenmişliği bireylerde fiziksel ve psikolojik olarak tükenme, kalıcı yorgunluk, enerji kaybı, olumsuz tutum ve davranış bozukluğu olarak tanımlamak mümkündür. Edelwich'e göre tükenmişlik kavramı "İnsanlara yardım eden mesleklerini icra eden kişilerde, çalışma koşullarının bir sonucu olarak; idealizm, enerji ve amaçta sürekli olarak artan kayıp şeklinde ifade etmiştir. Buradaki çalışma koşulları; yetersiz eğitim, müşteri yoğunluğu, uzun mesai saatleri, düşük ücret, yapılan işe minnet duymayan müşterilerle çalışma, bürokratik veya politik zorlamalar, kişisel idealler ve istekler ile ulaşılan nokta arasındaki farktır”. Tükenmişlik kavramı, çalışma koşulları ve kişisel isteklerin çatışması sonucunda meydana gelmektedir.

Tükenmişliğin boyutları bir dizi şeklinde birbirini takip etmekte olup; tükenmişlik duygusal olarak kendini yıpratmayla başlayıp, artış hissine bağlı olarak başka kişilere karşı kayıtsız davranışlar sergileyip duyarsızlaşmaya ve son olarakta kişinin kendini

39 Debra Jackson, Angela Firtko, Michel Edenborough, "Personal Resilience as A Strategy For Surviving and Thriving in The Face Of Workplace Adversity: A Literature Review", Journal of advanced nursing, 60/1 (2007), s.6. 40 Ebru Yıldız, "Mesleki Tükenmişlik ve Rehber Öğretmenler Üzerine Bir Araştırma”, Erciyes Üniversitesi Sosyal Bilimler Enstitüsü Dergisi, 1/33 (2012).

41 Christina Maslach, Susan E. Jackson, “The measurement of experienced burnout”, Journal of Organizational Behavior, 2/2 (1981).

42 Pelit Elbeyi, Fatih Türkmen, “Otel İşletmeleri İşgörenlerinin Tükenmişlik Düzeyleri: Yerli ve Yabancı Zincir Otel İşletmeleri İşgörenleri Üzerinde Bir Araştırma”, Gazi Üniversitesi İktisadi ve İdari Bilimler Fakültesi Dergisi, 10/1 (2008), s.102. 
olumsuz etkileyerek kişisel başarıda düşüme hissine ulaşmaktadır. ${ }^{43}$ Maslach ve Jackson'nın ${ }^{44}$ üç boyutu yazında en çok kullanılan tanımlamadır. Maslach'ın tükenmişlik modeline göre, tükenmişliğin başlangıcı ve en anlamlı belirtisi olan, bireysel stres boyutunu temsil eden duygusal tükenmedir. ${ }^{45}$ İnsanlarla birebir ilişkinin fazla olduğu meslek dallarında, çalışanlar yaptıkları işe bağlı olarak aşırı iş yükü olması sebebiyle kendilerini, yorgun ve yıpranmış hissetmekle beraber duygusal tükenme hissine kapılırlar. ${ }^{46}$ Duygusal tükenme bu kadar net ve en çok analiz edilen kriter olmasına rağmen, tek başına tükenmişlik tanısını koymaya yeterli değildir. ${ }^{47}$ Tükenmişliğin bir diğer önemli ve sorunlu boyutu duyarsızlaşmadır. Duyarsızlaşma, duygularından arınmış bir biçimde işine ve kişilere karşı insancıl olmayan ilgisiz, katı ve soğuk tavırlar sergilemesi olarak tanımlanmıştır. ${ }^{48}$ Duyarsızlaşma yaşayan kişiler iletişimi minimum seviyeye indirgemek isteyip, tek başına kalma hissine kapılırlar ve karşılarındaki bireyleri umursamaz ve kaba davranışlarda bulunup, mesafeli tavırlar sergileyerek, çevresindekilerin taleplerine cevap vermeyebilirler. Tükenmişliğin üçüncü ve son boyutu ise kişisel başarısızlıktır. Maslach’a göre kişisel başarı hissinin düşmesi, kişinin işinden tatmin olmayarak, yetersiz ve başarısız olduğunu düşünmesi olarak ifade edilirken ${ }^{49}$ tükenmişliğin bir sonucu olarak değerlendirilmektedir. ${ }^{50}$ Kişiler bütün negatifliklerin sonucu olarak, daha önceki pozitif tavırlarıyla, şu anki negatif tavırları arasındaki farkı ayırt ederek, hem işin de hem de insanlarla olan ilişkilerinde yetersizlik hissine kapılmaktadır. ${ }^{51}$

Duygusal tükenme ve duyarsızlaşma tükenmişliğin temel bileşini olarak görülürken, ${ }^{52}$ kişisel başarı hissinde azalma gerçek bir tükenmişlik bileşeninden ziyade bir kişilik özelliğini yansıttığ 1 için eleştirilmektedir. ${ }^{53}$ Daha önceki amprik çalışmalara bakıldığında, kişsel başarı hissinde düşüş boyutu diğer iki tükenmişlik boyutu ile düşük korelasyona sahip olduğu ${ }^{54}$ ve duyarsızlaşmanın duygusal tükenmeden sonra ortaya çıkarken, kişisel başarı hissinin diğer tükenmişlik boyutlarından bağımsız ve paralel olarak ortaya çımasi ${ }^{55}$ tükenmişiliğin üçüncü boyutu ile ilgili eleştirileri

43 Yıldız, "Mesleki Tükenmişlik ve Rehber Öğretmenler Üzerine Bir Araştırma”, s.38. 44 Maslach, C. ve Jackson, S. E., Journal Of Occupational Behaviour.

45 Christina Maslach, Wilmar B. Schaufeli, Michael P. Leiter, "Job burnout”, Annual review of psychology, 52/1 (2001).

46 Maslach, C. ve Jackson, S. E., Journal Of Occupational Behaviour; Veli Öztürk, Seyhan Çil Koçyiğit, Emine Çına BAL. "Muhasebe Meslek Mensuplarının Mesleki Tükenmişlik Düzeyleri İle İşe Bağlılık Arasındaki İlişkiyi Belirlemeye Yönelik Bir Araştırma: Ankara İli Örneği”, Doğuş Üniversitesi Dergisi, (2011).

47 Maslach vd., Annual Review Psychology.

48 Maslach, C. ve Jackson, S. E., Journal Of Occupational Behaviour; Maslach vd., Annual Review Psychology.

49 Maslach, C. ve Jackson, S. E., Journal Of Occupational Behaviour; Öztürk vd., "Muhasebe Meslek Mensuplarının Mesleki Tükenmişlik Düzeyleri İle İşe Bağlılık Arasındaki İlişkiyi Belirlemeye Yönelik Bir Araştırma: Ankara İli Örneği”.

50 Maslach vd., Annual Review Psychology, s.403.

51 Maslach vd., Annual Review Psychology.

52 Wilmar B. Schaufeli ve Toon W. Taris, "The Conceptualization and Measurement of Burnout: Common Ground and Worlds Apart”, Work \& Stress, 19/3 (2005).

53 Schaufeli ve Taris, "The Conceptualization and Measurement of Burnout: Common Ground and Worlds Apart".

54 Lee, Raymond T., ve Blake E. Ashforth, "A Meta-Analytic Examination of The Correlates of The Three Dimensions of Job Burnout", Journal of applied Psychology, 81/2 (1996).

55 Michael P. Leiter, Burnout as a developmental process: Consideration of models. haz. W. B. Schaufeli, C. Maslach, \& T. Marek, Washington, DC: Taylor \& Francis, 2001. Toon W. Taris, Pascale M. Le Blanc, Wilmar B. Schaufeli 
destekler niteliktedir. Ayrıca tükenmişlik yaşayan hastalarla ilgili klinik bulgularda, duygusal tükenme ve duyarsızlaşmanın birbiri ardına ortaya çıktığı gözlenirken, kişisel başarı eksikliğinin çok daha az sıklıkla gözlendiği iddia edilmektedir. ${ }^{56}$ Son olarak kişisel başarı boyutu tükenmişlik ölçeğinde olumlu ifadelerle ölçülürken, diğer iki tükenmişlik boyutu negatif ifadelerle ölçümlenmektedir, olumlu ve olumsuz ifadelerin faktör analizinde ayrı ayrı kümelenmesi muhtemel olmasından ötürü, kişisel başarı boyutu farklı bir faktör olarak ortaya çıkmaktadır. ${ }^{57} \mathrm{Bu}$ eleştriler doğrultusunda bu çalışmada tükenmişlik, dugusal tükene ve duyarsızlaşma olarak ele alınacaktır.

\section{İş Stresi, Pozitif Psikolojik Sermaye Ve Tükenmişlik Arasındaki İlişki}

Bireylerin yaşadığı yoğun iş stresi sonucu ortaya çıkan, duygusal ve davranışsal problemler bütününe tükenmişlik olarak isimlendirebiliriz. Tükenme, çalışanların kendi aralarında çıkan çatışmalar ve kişsel yetersizlikler sonucunda ortaya çıkan tükenmişlik hissi, duygusal tükenme ve duyarsızlaşma olarak ortaya çıkmaktadır. Tükenmişlik, bireyin düşük performans sergilemesi, işine gereken özeni gösterememesi ve işverenin verdiği işleri yerine getirememesi sonucunda, bireyde meydana gelen tükenmişlik duygusu toplumda sosyal bir sorun olarak kabul görmektedir. ${ }^{58}$

İş stresinin tükenmişliğe olan etkisinin anlaşılmasında yararlı olabilecek yaklaşım Kaynakların Korunma Teorisidir. Kaynakların Korunma Teorisi, bireylerin önemsediği kaynakları korumayı, arttırmayı ve bazı zamanlarda yeni kaynakları elde etmek için çabaladıklarını savunmaktadır. ${ }^{59}$ Bireyler ellerindeki kaynakları koruyamadığı, kaybettiği veya yeni kaynak elde edemedikleri zaman stres yaşamaktadırlar. Hobfoll $^{60}$ teorisinde bireylerin yeni kaynak bulmalarında başarılı olamadıklarında tükenmişlik duygusu yaşayacağını vurgulamıştır. ${ }^{61}$ Dolayısıyla daha az kaynağa sahip bireyler, kaynakların kaybolmasına dayanıksız olacak, buna bağlı stres ve sonrasında tükenmişlik duygusunu hızlı bir şekilde hissedeceklerdir.

Son 20 yılda iş stresi ve tükenmişlik arasındaki anlamı ilişki birçok yerli ve yabancı çalışmanın merak konusu olmuş ve halen incelenmeye devam etmektedir. Yüz yüze etkileşim ve iletişim artığı günümüz çalışma ortamında, özellikle hizmet sektöründe işin doğası gereği yaşanan yoğun stres sonucu tükenmişlik hissi özellikle doktorlar, ${ }^{62}$

ve Paul J. G. Schreurs, "Are There Causal Relationships Between The Dimensions of The Maslach Burnout Inventory? A Review and Two Longitudinal Tests". Work \& Stress, 19/3 (2005).

56 Qiao, Hu, and Wilmar B. Schaufeli, "The Convergent Validity of Four Burnout Measures in A Chinese Sample: A Confirmatory Factor-Analytic Approach”, Applied Psychology, 60/1 (2011), s.89.

$57 \mathrm{Hu}$ ve Schaufeli, "The Convergent Validity of Four Burnout Measures in A Chinese Sample: A Confirmatory Factor-Analytic Approach", s.90.

58 Bülbin Sucuoğlu,Neslihan. Kuloğlu, “Özürlü Çocuklarla Çalışan Öğretmenlerde Tükenmişliğin Değerlendirilmesi”, Türk Psikoloji Dergisi, 10/36 (1996).

59 Hobfoll, Applied Psychology.

60 Hobfoll, Applied Psychology.

61 Yürür, "Öğrenilmiş Güçlülük, Kıdem ve Medeni Durumun Duygusal Tükenmedeki Rolü: Kaynakların Korunması Teorisi Kapsamında Bir Analiz”, s.110.

62 Zhang, vd., "Mental Health And Burnout in Primary And Secondary School Teachers in The Remote Mountain Areas Of Guangdong Province in The People's Republic Of China”, s.123. 
hemşireler, ${ }^{63}$ öğretmenler, ${ }^{64}$ mali müşavirler, ${ }^{65}$ sağlık görevlileri, ${ }^{66}$ turizm ${ }^{67}$ ve banka çalışanları gibi farklı hizmet meslek guruplarında incelenmiştir. ${ }^{68}$

Onay ve Kılıcı'nın ${ }^{69}$ iş stresi ve tükenmişlik duygusunun işten ayrılma niyeti üzerine etkisini incelemek amacıyla yaptıkları araştırmalarında, iş stresi ile tükenmişlik arasında güçlü ve pozitif yönlü bir ilişki olduğu kanıtlanmıştır. Çalışanların bireysel stres ve iş yerinin fiziksel özelliklerine bağlı olan stres kaynaklarının, tükenmişlik boyutunun iki alt boyutu olan duygusal tükenme ve duyarsızlaşmayı pozitif yönde artırdığ 1 ortaya çıkmıştır. Erdoğan ve Ünsar’ın ${ }^{70}$ stresin çalışanlar üzerindeki etkilerine yönelik yaptıkları araştırmalarında, iş stresinin çalışanların olumsuz açıdan etkilediği, hem iş yerin de hem de özel hayatında istenmeyen durumların oluşmasına sebep olduğu sonucuna ulaşılmıştır.

Bankacılık sektöründe yapılan araştırmalardan; Baklacı'nın ${ }^{71}$ iş stresi ve tükenmişlik arasındaki ilişkiyi incelemek üzere banka çalışanları üzerinde yaptığı araştırmada, iş stresi ile tükenmişlik arasında pozitif ve anlamlı bir ilişki bulunmuştur. Çalışanların kendi yetenek ve becerilerini kullanamaması, örgüt içinde birlik ve beraberliğin olmaması, görev ve sorumluluklarında kendi insiyatifini kullanamaması, stres düzeylerinin artmasına, bunun sonucunda da tükenmişlik düzeylerinin artmasına sebep olduğu belirtilmiştir. Serinkan ve Aporavanın, 2018 yılında Kırgızistan'daki bankacılık sektöründe çalışanların yaşadığ yaptıkları çalışma da duygusal tükenmenin yüksek düzeyde, duyarsızlaşma boyutunun orta düzeyde, kişisel başarı boyutunun ise yüksek düzeyde olduğu bulunmuştur. ${ }^{72}$ Bir diğer bankacılık sektöründeki çalışma 2014 yılında Erkul ve arkadaşlarının tükenmişlik ile işten ayrılma niyeti arasındaki ilişkiyi belirlemek amacıyla yaptıkları araştırmadır. Çalışma sonuçlarında Gaziantep’te faaliyet gösteren banka çalışanlarının tükenmişlik düzeyi ile işten ayrılma niyeti arasında pozitif yönlü bir ilişki oldu-

63 Yim, Hee-Yun, vd. "Mediating Role of Psychological Capital in Relationship Between Occupational Stress and Turnover Intention Among Nurses At Veterans Administration Hospitals in Korea “.

64Selçuk Demir, “The Relationship between Psychological Capital and Stress, Anxiety, Burnout, Job Satisfaction, and Job Involvement”, Eurasian Journal of Educational Research, 75 (2018).

65 Gülsevim Günay, Tülay Yumuk Demiralay, ve Güney Çetin Gürkan, “Örgütsel İklimin İşkoliklik Üzerindeki Etkileri: Türk Zincir Otel Yöneticileri Üzerinde Bir Araştırma”, Kocaeli Üniversitesi Sosyal Bilimler Enstitüsü Dergisi, 33 (2017).

66 David Prosser, Sonia Johnson, Elizabeth Kuipers, George Szmukler, Paul Bebbington, Graham Thornicroft, "Perceived Sources of Work Stress and Satisfaction Among Hospital and Community Mental Health Staff, and Their Relation To Mental Health, Burnout and Job Satisfaction", Journal Of Psychosomatic Research, 43/1 (1997). 67 Onay ve Kılcı, "İş stresi ve tükenmişlik duygusunun işten ayrılma niyeti üzerine etkileri: Garsonlar ve Aşçıbaşılar",

68 Ersezgin ve Sevgi Tok, "Algılanan İş Stresi, Psikolojik Dayanıklılık, Başa Çıkma Stilleri ve Öz-Duyarlılığın Tükenmişlik Düzeyini Yordayıcı Etkisi”,

69 Meltem Onay, Sevde Kılc1, “İş Stresi ve Tükenmişlik Duygusunun İşten Ayrılma Niyeti Üzerine Etkileri: Garsonlar ve Aşçıbaşılar”, Organizasyon ve Yönetim Bilimleri Dergisi, 3/2 (2011).

70 Tolga Erdoğan, Sinan Ünsar, Necdet Süt, “Stresin Çalışanlar Üzerindeki Etkileri: Bir Araştırma”, Süleyman Demirel Üniversitesi İktisadi ve İdari Bilimler Fakültesi Dergisi, 14/2. (2009).

71 Eda Baklacı, “İş Stresi ve Tükenmişlik Arasındaki İlişki: Banka Çalışanları Üzerinde Bir Araştırma”, Mustafa Kemal Üniversitesi Sosyal Bilimler Enstitüsü, (2013).

72 Celaleddin Serinkan ve İbadathan Arapova, "Bankacılık Sektöründe Tükenmişlik Sendromu: Kırgızistan Örneği Burnout Syndrome In Bankıng Sector: Sample Of Kyrgyzystan”, Journal of Economics, 3/5 (2018). 
ğu ortaya çıkmıştır. ${ }^{73}$ Soygür ve Aydın'ın pazarlama ve satış hedef baskısının banka personeli üzerindeki etkisini ölçmek üzere yapmış oldukları çalışmada ise hedef baskısının çalışanların tükenmişlik hissini ve seviyesini artırdığı ancak iş stresi düzeyini artırmadığ 1 tam tersine azalttığı sonucuna varılmıştır. ${ }^{74}$

Ayrıca, Kaya’nın ${ }^{75} 2010$ yılında sağlık sektöründe yaptığı araştırma sonuçları da Onay ve Kılıcı'nın ${ }^{76}$ bulguları ile paralellik göstermektedir. Çalışanların stres duygusu azaldığında tükenmişlik duygusu da azalmaktadır. İş ortamında yaşanan stres hem birey hem de işletmeler için doğal bir olay olarak görülmekte ve karşı konulamaz bir sonuçtur. Ayrıca o ortamda çalışan bireyde memnuniyetsizlik, fiziksel ve zihinsel davranış bozukluklarına neden olmaktadır. ${ }^{77}$ İş stresi yüksek olan çalışanlar, üretkenliklerini minimum seviyeye indirip, verimli çalışmayı azaltarak, hizmet sunduğu bireylere karşı duyarsız bir tutum ve davranış gösterebilirler. Bu bağlamda iş stresi duyarsızlaşmanın artmasına sebep olmaktadır. ${ }^{78} \mathrm{Bu}$ çalışmalardan yola çıkarak aşağıdaki hipotez geliştirilmiştir;

$H_{1}$ : İş stresi duygusal tükenmeyi pozitif yönde etkiler.

$H_{2}$ : İş stresi duyarsızlaşmayı pozitif yönde etkiler.

Pozitif psikolojik sermaye kavramı özellikle Avey, Luthans ve Jensen ${ }^{79}$ ve Luthans ve $\operatorname{arkadaşları~}^{80}$ tarafından, işyerinden kaynaklanan olumsuzlukları gidermek ve çalışanları geliştirmek amacıyla kullanılabilecek bir araç olarak belirlenmiştir. Bir bütün olarak ortaya çıkan Pozitif psikolojik sermaye, bireyin özyeterliliği, iyimserliği, umudu ve dayanıklılığı ile açıklanabilen psikolojik bir durum olarak açıklanmıştır. Alan yazında, pozitif psikolojik sermaye ve boyutlarından öz yeterlilik, iyimserlik, umut ve dayanıklılık ile tükenmişlik boyutları arasında negatif bir ilişki tespit edilmiştir.

Altınkurt ve arkadaşları öğretmenlerin psikolojik sermayeleri ile tükenmişlik düzeyleri arasındaki ilişkileri incelemişlerdir. ${ }^{81}$ Araştırma sonuçlarına göre öğretmenlerin pozitif psikolojik sermayeleri, duygusal tükenmişlik düzeylerinin \%7’sini, duyarsılaşmanın ve kişisel başarısızlık duygusunun \%19’unu açıklamaktadır. Öğretmenler

\footnotetext{
73 Mehmet Halit Yıldırım, Emel Eylül Erul, ve Pınar Kelebek, “Tükenmişlik ile İşten Ayrılma Niyeti Arasındaki İlişki Banka Çalışanları Üzerine Bir Araştırma”, Organizasyon ve Yönetim Bilimleri Dergisi, 6/1 (2014).

74 İsmail Cüneyt Soygür ve Sonay Zeki Aydın, "Bankacılık Sektöründe Pazarlama ve Satış Yönlü Hedef Baskısının Banka Personeli Üzerindeki Etkisinin Analizi”, Suleyman Demirel University Journal of Faculty of Economics \& Administrative Sciences, 23/2 (2018).

75 Erhan, Kaya, "İş Stresi ve Tükenmişlik Duygusunun İşten Ayrılma Niyeti Üzerine Etkileri: Sağlık Personeli Üzerinde Bir Uygulama” Yüksek Lisans Tezi, Gebze Yüksek Teknolojileri Enstitüsü, 2010.

76 Onay ve Kılıcı, "İşs stresi ve tükenmişlik duygusunun işten ayrılma niyeti üzerine etkileri: Garsonlar ve Aşçıbaşılar".

77 Zeki Güler, Nuran Öztürk Başpınar, Hüseyin Gürbüz, İş yaşamında stres ve kamu kurumlarındaki sekreterler üzerinde bir uygulama. Eskişehir: T.C. Anadolu Üniversitesi Yayınları. 2000.

78 Onay ve Kılıcı "İş Stresi ve Tükenmişlik Duygusunun İşten Ayrılma Niyeti Üzerine Etkileri: Garsonlar ve Aşçıbaşılar”,

79 James B. Avey, Fred Luthans, Susan M. Jensen, "Psychological Capital: A Positive Resource for Combating Employee Stress and Turnover", Human resource management, 48/5 (2009).

80 Luthans vd. Psychological capital.

81 Yahya Altınkurt, Ertürk Abbas ve İlkay Yılmaz, "Öğretmenlerin Psikolojik Sermayeleri ile Tükenmişlik Düzeyle-ri Arasındaki İlişki”, Journal of Teacher Education and Educators, 4/2 (2015).
} 
üzerine yapılan bir başka çalışmada Tösten, Arslantaş ve Şahin, psikolojik sermaye bileşenlerinin tükenmişliği \%40 açıkladığı ve negatif etkisininin olduğunu bulmuştur. ${ }^{82}$ Ocak ve Gülerin, 2017 yılında Bosnalı öğretmenler üzerinde yaptığı çalışmada pozitif psikolojik sermaye boyutlarından, iyimserlik ve psikolojik dayanıklılığın tükenmişlik üzerinde etkisi olduğu; hatta psikolojik dayanıklılığın duyarsızlaşma üzerindeki etkisinin ters yönde olduğu görülmüştür. ${ }^{83}$ Çetin, Şeşen ve Basım’n Kamu sektöründe tükenmişlik süreçlerine etki eden pozitif psikolojik sermaye faktörlerinin ortaya çıkarılması amacıyla yaptığı araştırmada pozitif psikolojik sermaye unsurlarından "öz yeterlilik" ve "umut” faktörlerinin görece önemli bir rolü olduğu, buna paralel psikolojik sermayenin alt boyutlarından "psikolojik dayanıklılı" ve "iyimserlik" ile tükenmişlik alt boyutlarından duygusal tükenme arasında ters yönlü ilişkiler olduğu tespit edilmiştir. ${ }^{84}$ Topçu ve Ocak'da iş tatmini, pozitif psikolojik sermaye ve tükenmişlik arasındaki ilişkileri irdeledikleri benzer bir çalışmayı Sivas ve Bosna-Hersek'de faaliyet gösteren imalat firmalarında yapmışlardır. Araştırma sonuçları psikolojik sermayenin tükenmişliğgi azaltırken, iş tatmini artırdığını göstermiştir. ${ }^{85}$

Yurdışındaki çalışmalardan Lin'inn ${ }^{86}$ turizm sektöründe ve Ali ve Ali’nin ${ }^{87}$ Pakistan'daki hemşireler üzerinde yaptıkları çalışmalarda pozitif psikolojik sermaye ile tükenmişlik arasında ters yönlü ilişki olduğu, yine Rehman, Qingren, Latif, ve Iqbal'nin ${ }^{88}$ üniversite öğretim üyeleri üzerinde yaptıkları çalışmada öğretim üyelerinin psikolojik sermayeleri ile tükenmişlikleri arasında negatif yönde yüksek düzeyde korelayon olduğu görülmüştür. Gillert'in ${ }^{89}$ çalışmasında farklı örneklem gruplarında dahi pozitif psikolojik sermaye ile tükenmişlik arasında negatif ilişkinin olduğu ortaya konulmuştur, dolayısıyla psikolojik sermayenin arttırılmasıyla tükenmişliğin düşürülebileceği vurgulanmıştır. Sonuç olarak pozitif psikolojik sermaye ile tükenmişlik düzeyi arasında negatif yönlü bir ilişkinin olduğu, pozitif psikolojik sermayenin arttırılmasıyla tükenmişliğin azalacağı söylenebilir. Bu çalışmalardan yola çıkarak aşağıdaki hipotez geliştirilmiştir:

$H_{3}$ : Pozitif psikolojik sermaye duygusal tükenmeyi negatif yönde etkiler.

82 Rasim Tösten, İsmail H. Arslantaş, ve Gülay Şahin, “Öğretmenlerin Pozitif Psikolojik Sermayelerinin Tükenmişliğe Etkisi”, Yüzüncü Yil Üniversitesi Eğitim Fakültesi Dergisi, 14/1 (2017).

83 Metin Ocak ve Murat Güler, "Psikolojik Sermayenin Tükenmişlik Üzerine Etkisi: Görgül Bir Araştırma”, Erciyes Üniversitesi Iktisadi ve Idari Bilimler Faküeltesi Dergisi, 49 (2017).

84 Fatih Çetin, Harun Şeşen, ve H. Nejat Basım, "Örgütsel Psikolojik Sermayenin Tükenmişlik Sürecine Etkileri: Kamu Sektöründe Bir Araştırma”, Anadolu University Journal of Social Sciences,13/3 (2013).

85Mustafa Kemal Topçu ve Metin Ocak "Psikolojik Sermayenin Tükenmişlik Algısı Üzerine Etkisinde İş Tatmininin Aracılık Rolü: Türkiye ve Bosna-Hersek Sağlık Çalışanları Örneği, (Ulusal Yönetim ve Organizasyon Kongresi Bildiriler Kitabı, 2012).

86 Tsung-Liang Lin, “The Relationships Among Perceived Organization Support, Psychological Capital and Employees' Job Burnout in İnternational Tourist Hotels”, Life Sci Journal, 10/3 (2013).

87 Ali Nazim, ve Arshad Ali. "The Mediating Effect of Job Satisfaction Between Psychological Capital and Job Burnout of Pakistani Nurses", Pakistan Journal of Commerce and Social Sciences, 8/2 (2014).

88 Saif ur Rehman, Cao Qingren, Yasir Latif, Pervaiz Iqbal, "Impact of Psychological Capital on Occupational Burnout and Performance Of Faculty Members”, International Journal of Educational Management, 31/4 (2017).

89 Jeanne E Gillert. The Relationship of Psychological Capital And Burnout With Training and Peformance. Doctoral Dissertation. Unıversity of Oklahoma, 2014. 
$H_{4}$ : Pozitif psikolojik sermaye duyarsızlaşmayı negatif yönde etkiler.

Yerli ve yabancı yazın taraması yapıldığında bankacılık sektöründe iş stresi ve tükenmişlikle ilgili çalı̧malara rastlanırken, pozitif psikolojik sermaye ile tükenmişilik arasında az sayıda çalışmaya ulaşılmıştır. Ayrıca bankacılık sektöründe iş stresi, pozitif psikolojik sermaye ve tükenmişliğin birlikte ele alındığı yerli yazında hiç yabancı yazında sadece Li’nin çalışması bulunmuştur. ${ }^{90}$ Bankacıllk sektöründeki teknolojik gelişmeler ve rekabetin baskısı, çalışanlarda yoğun hedef ve iş yüküne neden olmaktdır. Oluşan bu baskılar bireylerde strese ve sonucunda tükenmişlik duygusana neden olmaktadır. Hizmet sektörünün yapısı gereği yaşanan stres duygusu yok olmayacaktır, aksine bireylerin bu duygularla başa çıkabilmesi için pozitif psikloijk sermaylerini güçlendirerek mümkün olabilecektir. Bu bağlamda, bu çalışmanın amacı iş stresi ve psikolojik sermayenin tükenmişlik algısı üzerindeki etkisini model olarak ele alarak bankacllık sektöründe ne düzeyde etkilediğini incelemektir.

Geliştirilen hipotezler doğrultusunda kurulan araştırma modeli Şekil l'de görülmektedir.

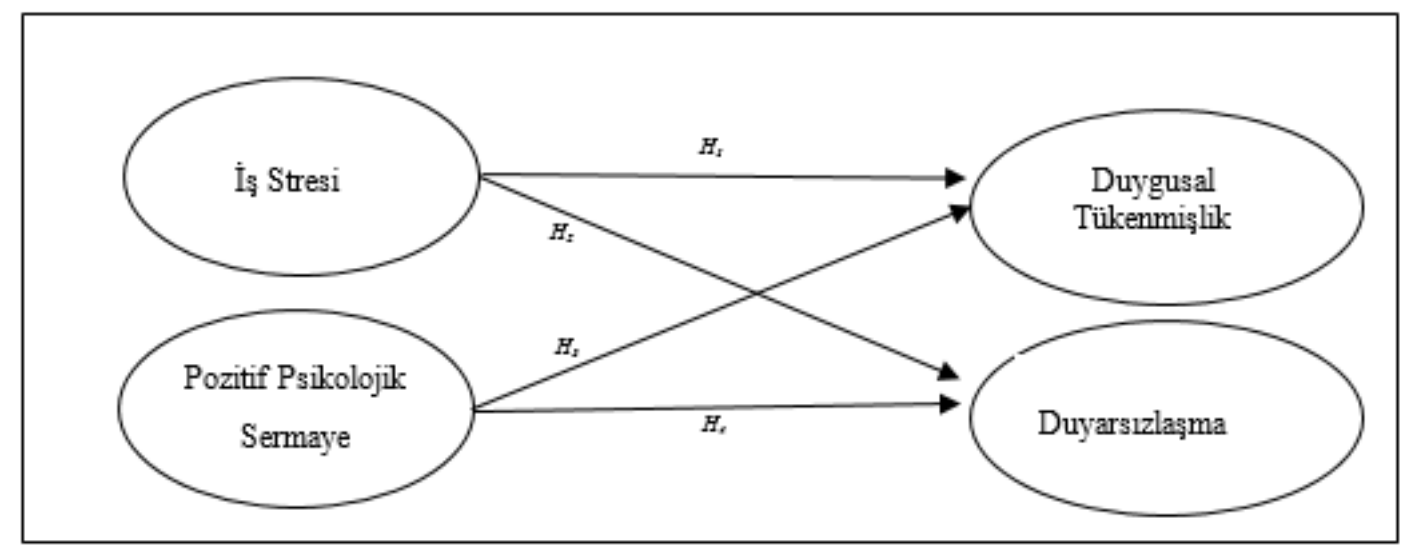

Şekil 1. Araştırma Modeli

\section{Ölçme Araçları ve Uygulama}

Araştırmada uygulama kısmında, öne sürülen hipotezleri test etmek amacı ile 3 fark$l_{1}$ ölçek kullanılmış olup bu ölçeklerin geçerlilikleri ve güvenilirlikleri test edilmiştir. Anket soru formu, demografik bilgilerin sorulduğu bölüm, iş stresi ölçeği, psikolojik sermaye ölçeği ve Maslach Tükenmişlik ölçeklerinden oluşmaktadır. Araştırmada kullanılan ölçekler, uluslararası geçerliliği ve güvenirliliği saptlanmış ve ulusal yazında orijinal dillerinden Türkçeye çevrilirip uyarlanarak geçerliliği ve güvenirliliği kanitlanmış ölçeklerdir.

İş stresi düzeylerini belirlemek üzere orjinali House ve Rizzo tarafından 1972 yllında

90 Xirui Li ,Dan Kan ,Li Liu ,Meng Shi ,Yang Wang ,Xiaoshi Yang ,Jiana Wang ,Lie Wang ve Hui Wu, “The Mediating Role of Psychological Capital on The Association Between Occupational Stress and Job Burnout Among Bank Employees in China", International Journal Of Environmental Research And Public Health, 12/3 (2015). 
geliştirilen ve Türk yazınında Efeoğlu ${ }^{91}$ ve Turunç ve Erkuş ${ }^{92}$ tarafından kullanılan güvenirliliği 0,90 olan 7 soruluk iş stresi ölçeği kullanılmıştır. Bu ölçek banka çalışanlarının iş yerinde yaşamış olduğu stresin ve stres ile ilgili psikolojik semptomları ölçmeye yönelik düzenlenmiştir.

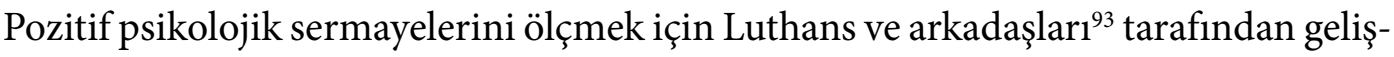
tirilen ve Erkuş ve Fındıklı94 tarafından Türkçe geçerliliği yapılan "Psikolojik Sermaye Anketi (PCQ-24)" kullanılmıştır. Pozitif psikolojik sermaye ölçeği birleşik bir üst yapı olarak öz yeterlilik, umut, psikolojik dayanıklılık ve iyimserlik boyutlarının toplamında 24 ifadeden oluşmaktadır. Luthans ve arkadaşları, pozitif psikolojik sermayenin kişilik özelliklerinden farklı olarak, dört boyutun bir araya gelerek, alt boyutların birbiriyle etkileşimi sonucunda ortaya çıkan özellikler olduğunu vurgulamıştır. $\mathrm{Bu}$ açıklamalar doğrultusunda analizlerde pozitif psikolojik sermaye alt boyutlarını birlikte ele alınarak analizler yapılmıştır.

Banka çalışanlarının tükenmişlik düzeylerini ölçmek için Maslach ve Jackson ${ }^{95}$ tarafindan geliştirilen, 22 madde ve 3 alt boyuttan oluşan ölçeğin, tükenmişlik kavramının temel boyutları olarak görülen duygusal tükenme ve duyarsızlaşma alt boyutları kullanılmıştır. Bunun için iki ayrı neden bulunmaktadır. İlk olarak tükenmişlik kavramının üçüncü alt boyutu olan kişisel başarı hissinde azalma, literatürde çokca eleştirilmektedir. Kişisel başarı hissinde azalma bir kişilik özelliğini yansıttığ 1 tükenmişlik hissinin bir sonucu olarak ortaya çıktığı literatürde tartışılmaktadır. ${ }^{96}$ Ayrıca daha önce yapılan araştırmalarda, kişsel başarı hissinde azalma boyutu diğer iki tükenmişlik boyutu ile düşük seviyede ilişkili olduğ ${ }^{97}$, kişisel başarı hissinin diğer tükenmişlik boyutlarından bağımsız ve paralel olarak ortaya çıktığı vurgulanmaktadır. ${ }^{98}$ İkinci olarak kişisel başarıda azalma hissinin kavramsal tanımının psikolojik sermaye ölçeğindeki öz-yeterlilik ile aynı olması nedeniyle çoklu bağlantılık (multicolinarity) hatasının önüne geçilmek istenmiştir.

Ölçeğin güvenilirlik değerleri duygusal tükenme alt boyutu için 0,83, duyarsızlaşma alt boyutu için 0,65 olarak tespit edilmiştir. Macit’in ${ }^{99}$ kullanmış olduğu tükenmişlik

91 İ. Efe Efeoğlu ve Hüseyin Özgen, "İş Aile Yaşam Çatışmasının İş Stresi İş Doyumu ve Örgütsel Bağlllık Üzerindeki Etkileri: İlaç Sektöründe Bir Araştırma”, Çukurova Üniversitesi Sosyal Bilimler Enstitüsü Dergisi, 16/2 (2007).

92 Ömer Turunç ve Ahmet Erkuş, "İş-Aile Yaşam Çatışmasının İş Tatmini ve Örgütsel Bağlılık Üzerine Etkileri: İş Stresinin Aracılık Rolü”, Sosyal Ekonomik Araştırmalar Dergisi, 10/19 (2010).

93 Luthans, F. vd., Positive Psychological Capital.

94 Erkuş ve Fındıklı, "Psikolojik Sermayenin İş Tatmini, İş Performansı ve İşten Ayrılma Niyeti Üzerindeki Etkisine Yönelik Bir Araştırma”, s.304.

95 Maslach, ve Jackson, "The measurement of Experienced burnout”.

96 Wilmar B. Schaufel, vd. "Burnout and work engagement: Independent Factors or Opposite Poles". Vicente González-Romá, Wilmar B. Schaufeli, Arnold B. Bakker ve Susan Lloret, "Burnout and Work Engagement: Independent Factors or Opposite Poles", Journal of Vocational Behavior, 68/1 (2006).

97Raymond ve Ashforth, "A Meta-Analytic Examination of The Correlates of The Three Dimensions of Job Burnout".

98 Leiter, Burnout as a developmental process: Consideration of models. Toon Taris vd., "Are There Causal Relationships Between The Dimensions of The Maslach Burnout Inventory? A Review and Two Longitudinal Tests".

99 Mustafa Macit, “İşkoliklik, İş - Aile Çatışması ve Tükenmişlik İlişkileri Üzerine Bir Araştırma”, Doktora Tezi, 
ölçeğinden faydalanılmıştır. Duygusal tükenmişlik alt boyutu 9 maddeden, duyarsızlaşma alt boyutu 5 maddeden oluşmaktadır.

\section{Örneklem}

Araştırmada, İstanbul ilininde faaliyet gösteren kamu ve özel banka genel müdürlük ve şubelerin de görev yapan çalışanlar yer almıştır. Kolayda örnekleme yöntemiyle 450 kişiye internet portalı üzerinden oluşturulan bir link aracılığıyla anketler dağıtılmıştır. Katılımcılara gönderilen anketlerde 300 tanesi kullanılabilir olarak çalışmaya dahil edilmiştir. Anketlerin geri dönüş oranın yüzde 66 olduğunu göstermektedir. Araştırma için anket dönüş oranının yeterli olduğu görülmüştür. Araştırmaya katılan banka çalışanlarının demoğrafik özelliklerini belirlemek amacıyla, tanımlayıcı istatistiksel analiz yapılmıştır. Bu analiz sonuçlarına ilişkin bulgular Tablo 1'de gösterilmiştir.

Tablo 1. Banka Çalışanlarının Demoğrafik Özelliklerine İlişkin Bulgular

\begin{tabular}{|llll|}
\hline Değişken & Tür & $F$ & $\%$ \\
Cinsiyet & Kadın & 161 & 53.7 \\
& Erkek & 139 & 56.3 \\
Yaş & $18-24$ & 18 & 6 \\
& $25-31$ & 112 & 37,3 \\
& $32-38$ & 116 & 38,7 \\
Medeni Durum & 39 ve üzeri & 54 & 18 \\
Sektör & Evli & 183 & 61 \\
& Bekar & 117 & 39 \\
Calışılan Birim & Kamu & 98 & 32,7 \\
Çalışma Süresi & Özel & 202 & 67,3 \\
& Şube & 98 & 64,7 \\
& Genel Müdürlük & 202 & 35,3 \\
& 1 ylldan az & 10 & 3,3 \\
& $1-5$ yll & 76 & 25,3 \\
& $6-10$ yıl & 87 & 29 \\
& $11-15$ yıl & 69 & 23 \\
\hline
\end{tabular}

Anketi cevaplayan çalışanların 161'i kadın, 139'u erkektir. Buna göre grubun yüzde 53,7’ i kadınlardan, yüzde 46,3'ü erkeklerden oluşmaktadır. Banka çalışanlarının yaş değişkenine göre 18’i (\%6) 18-24, 112'si (\%37,3) 25-31, 116’sı (\%38,7) 32-38, 54'ü (\%18) 39 ve üzeri olarak dağılmaktadır. Sektör değişkenine göre bakıldığında katılımcıların yüzde 32,7 (98) kamu, yüzde 67,3 (202) özel bankada çalışmaktadır. Banka çalışanlarının birim değişkenine göre yüzde 64,7’si (194) şube, süresi değişkenine göre 87’si (\%29,0) 6-10 yıl olarak dağılmaktadır. Eğitim durumu değişkenine göre

Gaziosmanpaşa Üniversitesi, 2015. 
ise çalışanların 199'unun (\%66,3) Üniversite, 53’ünün $(\% 19,0)$ Lisansüstü dereceye sahiptir. Ayrıca banka çalışanlarının yüzde 60,7’si evli ve yüzde 46,3’ü çocuk sahibidir.

\section{Bulgular}

Araştırmada değişkenlere ilişkin tanımlayıcı analizler, geçerlilik ve güvenilirlik testi için faktör analizleri ve Cronbach Alfa iç tutarlılık testi, korelasyon analizi ve çoklu regresyon analizleri kullanılmıştır. Analizler AMOS.21 ve SPSS 20 programlarıyla yapılmıştır.

İş stresi, pozitif psikolojik sermaye ve tükenmişlik arasındaki ilişkiler incelenmeden önce yapı geçerliliğini test etmek amacıyla tüm değişkenlerin ayrı ayrı faktör yapısı incelenmiştir. Çalışmada kullanılan iş stresi ölçeği, öncesinde yapılan farklı bir araştırmada kullanılmış olduğu için yine doğrulayıcı faktör analizi ile geçerliliği test edilmek istenmiştir. Analiz sonuçlarına göre faktör yükü 0,50'nin altında kalan 2 madde, analizden çıkartılmış, kalan 5 madde ile tek faktörlü yapı sınanmıştır. "İşimle ilgili sorunlar uyku sorunu yaşamama neden oluyor" ve "Evde olduğum zamanlar başka işler yapıyor olsam da sıklıkla işimle ilgili konular düşünüyorum” ifadelerini içeren bu maddelerin iş stresi açısından katılımcılarca yanlış algılanmış olabileceği düşünülmüştür. 5. ve 7. Maddeler ölçekten çıkarıldıktan sonra doğrulayıcı faktör analizi tekrarlanmıştır. Ölçek için belirlenen uyum iyiliği indekslerince incelendiğinde RMSEA 0,073; SRMR 0,025; CFI 0,99; DF 5; CMIN 12,941; CMIN/df 2,588 değerli ile kullanılmak için uygun durumda olduğuna kanaat getirilmiştir. Ayrıca, güvenilirliğin bir göstergesi olan Çıkartılan ortalama varyans 0,60 olarak bulunmuş, Cronbach Alpha iç tutarlılık katsayısının da 0,89 olduğu görülmüştür. Dolayısıyla, İş Stresi kavramının tek faktörlü yapısı doğrulanmış ve yapı geçerliliğine ve güvenilirliğine dair olumlu bir bulgu elde edilmiştir.

Araştırmada dört faktörden oluşan pozitif psikolojik sermaye ölçeği kullanılmıştır. Psikolojik sermaye, bileşenlerin toplamından oluşan bir kavram olduğu için tek faktörlü yapı ile test edilmiştir. Analiz sonuçlarına göre faktör yükü 0,50’nin altında kalan 10 madde, analizden çıkartılmış, kalan 14 madde ile tek faktörlü yapı sınanmıştır. Yansıtıcı ölçüm maddelerinde (reflective measures) doğrulayıcı faktör analizinde yükü düşük olan maddelerin analizden çıkarılabileceği daha önceki çalışmalarda önerilmiştir. ${ }^{100}$ Uygulanan tek faktörlü analiz sonuçlarına göre pozitif psikolojik sermaye ölçeğinin uyum indeksleri incelendiğinde RMSEA 0,074; SRMR 0,040; CFI 0,953; DF 74; CMIN 195,851; CMIN/df 2,647 değerlerince kullanılabilir olduğunu söylemek mümkündür. Ayrıca, güvenilirliğin bir göstergesi olan Çıkartılan ortalama varyans 0,52 olarak bulunmuş, Cronbach Alpha iç tutarlılık katsayısının da 0,94 olduğu görülmüştür. Dolayısıyla, Psikolojik Sermaye kavramının tek faktörlü yapısı doğrulanmış ve yapı geçerliliğine ve güvenilirliğine dair olumlu bir bulgu elde edilmiştir.

Tükenmişlik ölçeğinde 14 madde ile birincil düzey duygusal tükenme ve duyarsızlaşma olmak üzere iki faktörlü doğrulayıcı faktör analizi yapılmıştır. ${ }^{101}$ Ölçek için

100 Tim Coltman, Timothy M. Devinney, David F. Midgley, Sunil Venaik, "Formative versus reflective measurement models: Two applications of formative measurement", Journal of Business Research, 61/12 (2008). 101 Onay ve Kılıcı, "İş Stresi Ve Tükenmişlik Duygusunun İşten Ayrılma Niyeti Üzerine Etkileri: Garsonlar ve Aşçıbaşılar”. 
belirlenen uyum iyiliği indeksleri incelendiğinde RMSEA 0,083; SRMR 0,044; CFI 0,954; DF: 69; CMIN 211,440; CMIN/df: 3,064 ile kullanılmak için uygun durumda olduğuna kanaat getirilmiştir. Ayrıca, güvenilirliğin bir göstergesi olan Çıkartılan ortalama varyanslar duygusal tükenme için 0,59, duyarsızlık boyutu için ise 0,55 olarak bulunmuş, Cronbach Alpha iç tutarlılık katsayısının tüm ölçekte 0,96 duygusal tükenme alt boyutunda 0,93, duyarsızlaşma alt boyutunda ise 0,86 olduğu görülmüştür. Dolayısıyla, tükenmişlik kavramının iki faktörlü yapısı doğrulanmış ve yapı geçerliliğine ve güvenilirliğine dair olumlu bir bulgu elde edilmiştir. Araştırmada kullanılacak ölçeklerin doğrulayıcı faktör analizi sonuçları Tablo2'de özetlenmiştir.

Tablo 2. Doğrulayıcı Faktör Analizi Uyum İyiliği İndeksleri

\begin{tabular}{|l|c|c|c|c|c|c|}
\hline & $R M S E A$ & $S R M R$ & $C F I$ & $C M I N$ & $D F$ & $C M I N / d f$ \\
\hline İş Stresi Ölçeği & 0,073 & 0,025 & 0,99 & 12,941 & 5 & 2,588 \\
\hline $\begin{array}{l}\text { Pozitif } \\
\begin{array}{l}\text { Psikolojik } \\
\text { Sermaye Ölçeği }\end{array}\end{array}$ & 0,074 & 0,040 & 0,953 & 195,851 & 74 & 2,647 \\
\hline $\begin{array}{l}\text { Tükenmişlik } \\
\text { Ölçeği }\end{array}$ & 0,083 & 0,044 & 0,954 & 211,440 & 69 & 3,064 \\
\hline
\end{tabular}

Çalışanların pozitif psikolojik sermaye, duygusal tükenme, duyarsızlaşma ve iş stresi arasında korelasyon analizleri incelendiğinde: Pozitif psikolojik sermaye ile duygusal tükenme arasında zayıf, negatif yönde anlamlı ilişki bulunmaktadır $(\mathrm{r}=-0.212$; $\mathrm{p}<0,01)$. Pozitif psikolojik sermaye ile duyarsızlaşma arasında zayıf, negatif yönde anlamlı ilişki bulunmaktadır $(\mathrm{r}=-0.157 ; \mathrm{p}<0,01)$. Pozitif psikolojik sermaye ile iş stresi arasında zayıf, negatif yönde anlamlı ilişki bulunmaktadır $(r=-0.180 ; p<0,01)$. Tükenmişliğin iki alt boyutu olarak duygusal tükenme ile duyarsızlaşma arasında ise yüksek ve pozitif yönde anlamlı bir ilişki bulunmaktadır $(r=0.948 ; p<0,01)$. Duygusal tükenme ile iş stresi arasında yüksek, pozitif yönde anlamlı ilişki bulunmaktadır $(\mathrm{r}=0.854 ; \mathrm{p}<0,01)$. Duyarsızlaşma ve iş stresi arasında yüksek, pozitif yönde anlamlı ilişki bulunmaktadır $(\mathrm{r}=0.808 ; \mathrm{p}<0,01)($ Tablo2 $)$.

Tablo 3. Çalışanların pozitif psikolojik sermaye, duygusal tükenme, duyarsılaşma ve iş stresi niyetleri arasında korelasyon analizi

\begin{tabular}{|c|c|c|c|c|c|c|}
\hline & Değişkenler & Ortalama & $\begin{array}{c}\text { Standart } \\
\text { Sapma }\end{array}$ & 2 & 3 & 4 \\
\hline 1 & $\begin{array}{l}\text { Pozitif Psikolojik } \\
\text { Sermaye }\end{array}$ & 4.121 & 0.626 & $-.212^{* *}$ & $-.157^{* *}$ & $-.180^{* *}$ \\
\hline 2 & Duygusal Tükenme & 3.3692 & 1.131 & & $.948^{* *}$ & $.854^{* *}$ \\
\hline 3 & Duyarsızlaşma & 2.7487 & 0.938 & & & $.808^{* *}$ \\
\hline 4 & İş Stresi & 2.5453 & 0.779 & & & \\
\hline
\end{tabular}

$\mathrm{Bu}$ çalışma da iş stresi ve psikolojik sermaynin, duygusal tükenme ve duyarsızlaşma arasındaki ilişkileri ele alınmıştır. Bu yüzden regresyan analizlerinde bağımsız değiş- 
kenlerin bağımlı değişken üzerindeki etkisi aynı anda test edilmiştir.

Tablo 4'de görüldüğü üzere ilk modelde, iş stresi ve pozitif psikolojik sermaye bağımsız değişkenlerinin duygusal tükenme bağımlı değişkeni ile arasında anlamlı bir ilişki olup olmadığını belirlemek üzere regresyon analizi uygulanmıştır ve modelin anlamlı olduğu görülmüştür $(\mathrm{F}=406,059 ; \mathrm{p}=0,000)$. Duygusal tükenmenin yorday1cısı olarak bağımsız değişkenlerin (iş stresi ve pozitif psikolojik sermaye ) açıklayıcılık gücünün güçlü olduğu görülmüştür $\left(\mathrm{R}^{2}=0,732\right)$. Çalışanların iş stresi düzeyi duygusal tükenme düzeyini arttırmaktadır $(\beta=0,84 ; \mathrm{p}<.01)$. Çalışanların pozitif psikolojik sermayeleri düzeyinin ise duygusal tükenme düzeyini azalttığ görülmüştür $(ß=-0,06 ; \mathrm{p}<0.5)$. Buna göre belirtilen hipotezlerden $H_{1}$ ve $H_{3}$ kabul edilmiştir.

İkinci regresyon modelinde iş stresi ve pozitif psikolojik sermaye bağımsız değişkenlerinin duyarsızlaşma bağımlı değişkeni ile arasında anlamlı bir ilişki olduğu görülmüştür $(\mathrm{F}=280,380 ; \mathrm{p}=0,000)$. Duyarsızlaşmanın belirleyicisi olarak iş stresi ve pozitif psikolojik sermayenin açıklayıcılık gücünün güçlü olduğu görülmüşsür $\left(\mathrm{R}^{2}=0,654\right)$. Çalışanların iş stresi düzeyi duyarsızlaşma düzeyini arttırmaktadır $(\beta=0,80 ; \mathrm{p}<.01)$. Çalışanların pozitif psikolojik sermayeleri düzeyinin ise duyarsızlaşmayı etkilemediği görülmüştür $(ß=-0,012 ; \mathrm{p}=0,73)$. Buna göre belirtilen hipotezlerden $\mathrm{H}_{2}$ kabul edilirken ve $\mathrm{H}_{4}$ reddedilmiştir.

Ayrıca hipotezlendirmediğimiz demografik ve sosyal özelliklerin iş stresi, pozitif psikolojik sermaye ve duygusal tükenme ve duyarsızlaşma üzerindeki etkileri de irdelenmiştir. Bu bağlamda araştırmaya katılan çalışanların cinsiyet değişkenine göre t testi uygulanmış ve anlamlı bir fark bulunmuştur. Erkeklerin psikolojik sermayesinin kadınlara göre daha yüksek olduğu görülmüştür $(t=-3,037, p<0,05)$. Stres düzeyi bakımından ise kadınların ortalamasının erkeklere göre daha yüksek olduğu bulunmuştur ( $\mathrm{t}=2,168, \mathrm{p}=0,031)$. Araştırmaya katılan özel banka çalışanların stres seviyesinin kamu bankalarından daha yüksek olduğu görülmüştür $(\mathrm{t}=-2,123, \mathrm{p}=0,035)$.

Tablo 4. İşstresi ve pozitif psikolojik sermayenin tükenmişliğin alt boyutları üzerindeki etkisi

\begin{tabular}{|c|c|c|c|c|c|c|}
\hline & \multicolumn{3}{|l|}{ Model 1} & \multicolumn{3}{|l|}{ Model 2} \\
\hline & \multicolumn{3}{|c|}{ Duygusal Tükenme } & \multicolumn{3}{|c|}{ Duyarsızlaşma } \\
\hline Bă̆ımsız Değişken & $\operatorname{Std} \beta$ & $t$ & $p$ & $\operatorname{Std} \beta$ & $t$ & $p$ \\
\hline Sabit & & 2,581 & 0,01 & & 1,369 & 0,17 \\
\hline İş Stresi & 0,843 & 27,606 & 0,00 & 0,806 & 23,227 & 0,00 \\
\hline Pozitif Psikolojik Sermaye & $-0,060$ & $-1,981$ & 0,48 & $-0,012$ & $-0,346$ & 0,73 \\
\hline $\mathrm{F}$ & \multicolumn{3}{|c|}{406,059} & \multicolumn{3}{|c|}{280,380} \\
\hline Model (p) & \multicolumn{3}{|c|}{0,000} & \multicolumn{3}{|c|}{0,000} \\
\hline $\mathrm{R}^{2}$ & \multicolumn{3}{|c|}{0,732} & \multicolumn{3}{|c|}{0,654} \\
\hline
\end{tabular}

Son olarak araştırmaya katılan çalışanların çalıştıkları birim değişkenine göre t testi uygulanmış ve anlamlı bir fark bulunmuştur. Genel müdürlük çalışanlarının psikolojik sermayeleri şube çalışanlarından daha yüksek olduğu bulunmuştur $(t=-2,088$, 
$\mathrm{p}=0,038)$. Şube çalışanlarının duygusal tükenmişliği ise genel müdürlük çalışanlarından daha yüksek olduğu görülmüştür. $(t=2,047, p=0,042)$. Şube çalışanlarının aynı zaman da stres düzeyi genel müdürlük çalışanlarından daha fazla olduğu görülmüştür $(\mathrm{t}=2,349, \mathrm{p}=0,019)$.

\section{Sonuç ve Öneriler}

$\mathrm{Bu}$ araştırma finans sektöründe faaliyet gösteren banka çalışanları üzerinde yapılmış, öne sürülen model çerçevesinde kamu ve özel banka çalışanlarının iş stresi ve pozitif psikolojik sermayelerinin tükenmişlik üzerindeki etkisileri incelenmiştir. Ulusal ve uluslararası yazın incelendiğinde bankacılık sektöründe iş stresi, pozitif psikolojik sermaye ve tükenmişlik üzerine çalışmalar olduğu, fakat bu kavramların daha çok ikili ve alt boyutları arasındaki ilişkilere odaklandığı görülmüştür. Dolayısıyla bu araştırma gerek iş stresi, pozitif psikolojik sermaye ve tükenmişlik değişkenlerinin birlikte ele alınarak incelenmesi, gerekse örneklemin Türkiye'deki bankacılık sektöründen seçilmesi bakımından literatüre katkı sağlaması açısından önemlidir.

Araştırmanın analizler aşamasında iş stresi tek boyutta ve pozitif psikolojik sermayenin dört alt bileşeni birleştirilerek tek boyutta ele alınırken, tükenmişlik değişkeni, duygusal tükenme ve duyarsızlaşma olmak üzere iki boyutta ele alınmıştır. Çalışmanın analiz sonuçlarına bakıldığında, iş stresinin tükenmişliğin her iki boyutla da anlamlı bir ilişkisi bulunmuştur.

Daha önce yapılmış araştırmaların bulguları incelendiğinde, benzer sonuçların çıktığı, başka bir deyişle iş stresi ile tükenmişlik arasında yüksek ve aynı yönlü ilişkinin olduğu gözlenmiştir. Çalışmamızın bulguları Onay ve Kılıcın ${ }^{102}$ çalışma sonucu olan bireysel stres ve iş yerinin fiziksel özelliklerine bağlı olan stres kaynakların tükenmişlik boyutunun iki alt boyutu olan duygusal tükenme ve duyarsızlaşmayı artırdığı sonucuyla destekler niteliktedir. Bununla beraber analiz bulguları bankacılık sektöründe Baklacı ${ }^{103}$ ve Serinkan \& Aporava'nın ${ }^{104}$ çalışmalarıyla benzer sonuçlara ulaşılırken, Soygür ve Aydının hedef baskısının iş stresi düzeyini azaltığı sonuçları ile ters sonuçlara ulaşılmıştır. Daha önce de bahsedildiği üzere hizmet sektörünün bel kemiği olan bankacılık sektöründe çalışanların hissettiği yoğun stres duygusu ancak stresle baş edilerek azaltılabilecektir. Pozitif psikolojik sermayenin bütününü oluşturan öz-yeterlilik, iyimserlik, umut ve dayanıklılığın güçlendirilmesiyle, çalışanların hissetikleri iş stresi azalacak ve böylece tükenmişlik düzeyleride azalacaktir. $^{105}$

Öte yandan araştırmada, pozitif psikolojik sermayenin tükenmişliğin alt boyutlarına

102 Onay ve Kılcı, “İş Stresi Ve Tükenmişlik Duygusunun İşten Ayrılma Niyeti Üzerine Etkileri: Garsonlar ve Aşçıbaşılar”.

103 Baklacı, "İş Stresi ve Tükenmişlik Arasındaki İlişki: Banka Çalışanları Üzerinde Bir Araştırma”. 104 Serinkan ve Arapova, "Bankacılık Sektöründe Tükenmişlik Sendromu: Kırgızistan Örneği Burnout Syndrome In Bankıng Sector: Sample Of Kyrgyzystan”.

105 Ersezgin ve Sevi Tok, "Algılanan İş Stresi, Psikolojik Dayanıklılık, Başa Çıkma Stilleri Ve Öz-Duyarlılığın Tükenmişlik Düzeyini Yordayıcı Etkisi”, s.6. 
göre değişiklik gösterdiği görülmüştür. Pozitif psikolojik sermaye duygusal tükenmişliği anlamlı ve negatif şekilde etkilerken, pozitif psikolojik sermayenin duyarsızlaşma üzerine anlamlı etkisine rastlanmamıştır. Pozitif psikolojik sermayenin duygusal tükenmişliği \%6 açıklaması, Altınkurt ve arkadaşlarının öğretmenler üzerinde yaptıkları çalışmayla benzerlik göstermektedir ${ }^{106}$. Ayrıca Topçu ve Ocak’ın pozitif psikolojik sermaye boyutlarının tükenmişlik üzerine ters etkisi de bir diğer benzer bulgudur. ${ }^{107}$

Alanyazında doğrudan bu araştırmanın sonuçlarıyla karşılaştırılabilecek sadece Li ve arkadaşlarını 2015 yılında Çin banka sektöründe yaptıkları araştırma bulunmaktadır. ${ }^{108} \mathrm{Bu}$ araştırma 1739 banka çalışanı üzerinde yapılmıştır. Bu çalışmanın sonuçları ile Çinli Banka çalışanlarının pozitif psikolojik sermayelerinin duygusal tükenme ve duyarsızlaşma üzerindeki ters ilişkisi benzerlik göstermektedir. ${ }^{109}$ Her iki çalışmada da banka çalışanlarının pozitif psikolojik sermayleri artıkça duygusal tükenme ve duyarsızlaşmaları azalacaktır. Çalışanların yeteneklerine olan güvenlerinin artması, gelecek için hedeflerini belirlemeleri ve bu bağlamda çaba sarf etmeleri ortaya çıkabilecek stres ve tükenmişlik ile baş edebileceklerinin göstergesidir. ${ }^{110} \mathrm{Bu}$ sonuçlar doğrultusunda banka yöneticilerinin çalışanlarını desteklemeleri, kişisel yetenek ve yetkinliklere uygun ödüller belirlenmeleri, pozitif bireysel kaynakların arttırılması için eğitimler verilmesi önerilmektedir. Pozitif psikolojik kaynakların güçlendirilmesi iş tatmini ve performansı artırırken, bireylerin stresten koruyup, tükenmişlik oranlarını da azaltacaktır. ${ }^{111}$ Ayrıca çalışanların iş yüklerinin adil iş bölümleri ve delegasyonlarla hafifletilerek, stres kaynaklarının azaltılması, gerektiğinde yoga, meditasyon gibi çeşitli stresle başa çıkma ve yönetebilme faaliyetleriyle desteklenerek tükenmişlik düzeylerinin azalması beklenmektedir.

Araştırmaya katılan banka çalışanlarının cinsiyet değişkeni açısından anlamlı bir farklılık gösterip göstermediğini belirlemek amacıyla yapılan analiz sonuçlarına göre kadın çalışanları stres seviyesi, erkek çalışanlardan daha yüksek olduğu bulunmuştur. Yirik, Ören ve Dikici’nin, ${ }^{112} 2014$ yılında otel işletmelerinde, çalışanlar üzerinde yaptığı araştırmada benzer şekilde kadın çalışanların stres düzeyleri, erkek çalışanlardan fazla çıkmıştır. Cinsiyet demografik değişkeni dışında, banka çalışanlarının sektör değişikeni açısında anlamlı bir farklılık gösterdiği görülmüştür. Özel banklarda ça-

106 Altınkurt, Ertürk ve Yılmaz “Öğretmenlerin Psikolojik Sermayeleri ile Tükenmişlik Düzeyleri Arasındaki İlişkide Psikolojik ve Yapısal Güçlendirmenin Rolü”, s.178.

107 Topçu, Mustafa Kemal, and Metin Ocak, "Psikolojik Sermayenin Tükenmişlik Algısı Üzerine Etkisinde İş Tatmininin Aracılık Rolü: Türkiye ve Bosna-Hersek Sağlık Çalışanları Örneği.”

$108 \mathrm{Li}$, vd. "The Mediating Role Of Psychological Capital on The Association Between Occupational Stress and Depressive Symptoms Among Chinese Physicians: A Cross-Sectional Study”.

$109 \mathrm{Li}$, vd. "The Mediating Role Of Psychological Capital on The Association Between Occupational Stress and Depressive Symptoms Among Chinese Physicians: A Cross-Sectional Study”, s.2996.

110 Çetın, Şeşen, Basım, “Örgütsel Psikolojik Sermayenin Tükenmişlik Sürecine”.

$111 \mathrm{Li}$, vd. "The Mediating Role of Psychological Capital on The Association Between Occupational Stress and Depressive Symptoms Among Chinese Physicians: A Cross-Sectional Study", s.2996.

112 Sevket Yirik, Deniz Oren, Remziye Ekici, "Dört Ve Beş Yıldızlı Otel İşletmelerinde Çalışan Personelin Örgütsel Stres Ve Örgütsel Tükenmişlik Düzeyleri Arasındakı İlişkilerin Demografik Değişkenler Bazında İncelenmesi”, Journal of Yaşar University, 9/35 (2014). 
lişanların stres düzeyleri, kamu bankalarındaki çalışanlara göre daha yüksek olduğu bulunmuştur. Bunun nedeninin özel bankalardaki rekabettin fazla olması nedeniyle çalışanlara daha fazla hedef, iş yükü ve baskı uygulaması olduğu düşünülmektedir. Ayrıca genel müdürlük çalışanlarının stres düzeyinin şube çalışan stres düzeyinden daha az olduğu bulunmuştur. Bu bulgunun nedeni olarakta şube çalışanlarının, müşteriler ile yüz yüze ilişkide bulunması ve bu bağlamda hem yöneticilerinin baskısına, hem de müşterilerin baskısına maruz kalmaları olarak düşünülmektedir.

Çalışanların tükenmişlik algılarına bakıldığında çalıştıkları birim bakımından farklılık gösterdiği görülmüştür. Araştırmaya göre şube çalışanlarının duygusal tükenmişliği genel müdürlük çalışanlarından daha yüksek olduğu tespit edilmiştir. Bunun sebebinin şube çalışanlarının müşteriler ile yüz yüze iletişiminin daha yüksek olmasına bağlı oluşan stresin, tükenmişlik ile paralel seviyede artmasıdır.

Pozitif psikolojik sermaye algısının çalışanların sadece cinsiyetine göre farklılık gösterdiği ortaya çıkmıştır. Araştırmaya katılan erkek çalışanların psikolojik sermayesi kadınlara göre daha yüksek olduğu görülmüsstür ki bu sonuçlar Kaya ve Altınkurt'un $^{113}$ çalışmasını desteklemektedir.

Literatüre bakıldığında finans sektörünün en kritik hizmet sağlayacısı olarak bankacllık sektöründe iş stresi ve pozitif psikolojik sermayenin, tükenmişlik üzerine etkisini araştıran çok fazla çalışma olmadığı görülmüştür, daha fazla araştırma yapılması gerekliliği ortaya çıkmaktadır. Bununla birlikte, bu çalışma sadece İstanbul ilindeki özel ve kamu banka çalışanlarına yapılmıştır. Ülkemiz genelinde ve farklı meslek gruplarında da daha kapsamlı araştırmalar yapılması önerilmektedir.

\section{Kaynakça}

Altınkurt, Yahya., Abbas Ertürk ve İlkay Yllmaz. "Öğretmenlerin Psikolojik Sermayeleri ile Tükenmişlik Düzeyle-ri Arasındaki İlişki”. Journal of Teacher Education and Educators. 4/2 (2015): 166-187.

Akgündüz, Sevgül. “Örgütsel Stres Kaynaklarının Çalışanların İş Tatmini Üzerindeki Etkisi ve Banka Çalışanları İçin Yapılan Bir Araştırma”. Yüksek Lisans Tezi, Dokuz Eylül Üniversitesi, 2006.

Akıncı, Z. Beril. "Kurum kültürü ve örgütsel iletişim." İstanbul: İletişim Yayınları. 122/127 (1998).

Akkoyun, Necip. "Örgütsel Stres, A-Tipi Kişilik ve Stresle Başaçıkma: Jandarma Genel Komutanlığında Bir Uygulama”. Yüksek lisans Tezi, Kara Harp Okulu, 2004.

Arık, İ. Alev. Motivasyon ve Heyecana Giriş. İstanbul: Çantay Kitabevi, 1996.

113 Çağlar Kaya ve Yahya Altınkurt, “Öğretmenlerin Psikolojik Sermayeleri ile Tükenmişlik Düzeyleri Arasındaki İlişkide Psikolojik ve Yapısal Güçlendirmenin Rolü”, Eğitim ve Bilim, 43/193 (2018). 
Armutcuk, Ali Kemal. "Denizli Devlet Hastanesinde Çalışmakta Olan Hekim Dışı

Sağlık Personelinde Tükenmişlik Sendromu ve İlişkili Değişkenler”. Yüksek Lisans Tezi, Pamukkale Üniversitesi, 2010.

Aydın, İnayet. İş yaşamında Stres. Ankara: Pegem A yayıncılık, 2008.

Aydogan, Enver ve Arzu Uğurlu Kara. "Pozitif Psikolojik Sermaye İle Bireysel

Performans İlişkisi: Türkiye Tarım Kredi Kooperatifi Merkez Birliği Örneği”. Third

Sector Social Economic Review. 50/1 (2015): 68-91.

Aydoğan, Oğuz. "İş Stresinin Tükenmişlik ve Örgütsel Bağlılıkla İlişkisi Kamu

Sektöründe Bir Uygulama”. Yüksek lisans Tezi, Kara Harp Okulu, 2008.

Aytaç, Mustafa ve Burcu Öngen. "Doğrulayıcı Faktör Analizi ile Yeni Çevresel Paradigma Ölçeğinin Yapı Geçerliliğinin İncelenmesi”. İstatistikçiler Dergisi, 5 (2012): 14-22.

Aytaç, Serpil. İş Stresi Yönetimi El Kitabı İşs Stresi: Oluşumu, Nedenleri, Başa Çıkma Yolları, Yönetimi. Ankara: Çasgem Yayınları, 2009.

Aziz, Aysel. Sosyal Bilimlerde Araştırma Yöntemleri Ve Teknikleri (Geliştirilmiş 6.bs.). Ankara: Nobel Yayıncilık, 2011.

Baklacı, Eda. "İş Stresi Ve Tükenmişlik Arasındaki İlişki: Banka Çalışanları Üzerinde Bir Araştırma”. Yüksek lisans Tezi, Mustafa Kemal Üniversitesi, 2013.

Baltaş, Acar ve Zulal Baltaş. Stres ve Başa Çıkma Yolları. İstanbul: Remzi Kitapevi, 2008.

Başaran, İ. Ethem. Örgütsel Davranış: Insanın Üretim Gücü. Ankara: Gül Yayınevi, 1991.

Beehr, Terry A. ve John E Newman. "Job Stress, Employee Health, and Organizational Effectiveness: A Facet Analysis, Model, And Literature Review”. Personnel psychology. 31/4 (1978): 665-699.

Bonanno, George A. "Loss, Trauma, and Human Resilience: : Have we underestimated the human capacity to thrive after extremely aversive events?". American Psychologist. 59/1 (2004): 20-28.

Büber, Harun. "Kurumsal Yönetim İlkelerini Uygulama Derecesi ile Performans Arasındaki İlişki: İMKB'de Faaliyette Bulunan Aile İşletmeleri Üzerine Bir Uygulama”. Doktora Tezi, Dumlupınar Üniversitesi, 2008.

Büyüköztürk, Şener. "Faktör Analizi: Temel Kavramlar ve Ölçek Geliştirmede Kullanımı.” Kuram ve Uygulamada Eğitim Yönetimi. 32/4 (2002): 470-483.

Büyüköztürk, Şener. Sosyal Bilimler İçin veri Analizi El Kitabı: İstatistik, Araştırma Deseni SPSS Uygulamaları ve Yorum. Ankara: Pegem Yayıncılık, 2011.

Cam, Erdem. "Çalışma Yaşamında Stres ve Kamu Kesiminde Kadın Çalışanlar”. Journal of Human Sciences. 1/1 (2006): 1-45.

Scheier, Michael F. ve Charles S. Carver. Optimism Handbook of Positive Psychology. Oxford: Oxford University Press, 2002.

Coltman, Tim, Timothy Devinney, David Midgley ve Sunil Venaik. "Formative Versus Reflective Measurement Models: Two Applications of Formative Measurement". Journal of Business Research. 61/12 (2008): 1250-1262. 
Coşar, Süreyya. “Çalışanların Tükenmişlik Düzeyleri İle Kendini Sabotaj Düzeyleri Arasındaki İlişkinin İncelenmesi”. Yüksek Lisans Tezi. Maltepe Üniversitesi, 2012.

Cox, Tom. Stress Research And Stress Management: Putting Theory To Work. Sudbury: Hse Books, 1993.

Cüceloğlu, Doğan. İnsan ve Davranışı. İstanbul: Remzi Kitabevi. 2015.

Çapık, Cantürk. "Geçerlik ve Güvenirlik Çalışmalarında Doğrulayıcı Faktör Analizinin Kullanımı”. Anadolu Hemşirelik ve Sağlık Bilimleri Dergisi. 17/3 (2012): 196-205.

Çetin, Fatih, Harun Şeşen ve Nejat H. Basım. "Örgütsel Psikolojik Sermayenin Tükenmişlik Sürecine Etkileri: Kamu Sektöründe Bir Araştırma”. Anadolu University Journal of Social Sciences. 13/3 (2013): 95-104.

Demir, S. “The Relationship between Psychological Capital and Stress, Anxiety, Burnout, Job Satisfaction, and Job Involvement". Eurasian Journal of Educational Research.75 (2018): 137-153.

Dinçerol, Cem. “Tükenmişlik Sendromunun Mesleki Tükenmişlik ve İş Tükenmişliği Açısından İncelenmesi: Öğretmenler Üzerinde Bir Uygulama”. Yüksek Lisans Tezi, Gazi Üniversitesi, 2013.

Efeoğlu, İbrahim Efe. "İş-Aile Yaşam Çatışmasının İş Stresi, İş Doyumu ve Örgütsel Bağlılık Üzerindeki Etkileri: İlaç Sektöründe Bir Araştırma”. Doktora Tezi, Çukurova Üniversitesi, 2006.

Eğin, Ayşe. “Çalışma Hayatında İş Stresi ve Tükenmişlik”. Yükssek Lisans Tezi, Beykent Üniversitesi, 2015.

Ekinci, Hasan ve Süleyman Ekici. "Yöneticiler Üzerindeki Etkileri Açısından Stres Kaynakları Ve Bir Uygulama”. Uludağ Üniversitesi İİBF Dergisi. 22/2 (2003): 93111.

Ellez, A. Ölçme Aracında Bulunması Gereken Özellikler. A.Tanrı̈ğen (Çev.), Ankara: Anı Yayıncilık, 2011.

Erdoğan, İlhan. İşletme Yönetiminde Kişiliğe Bağh Çatışma, Stres Ve Çözüm Yolları. Ankara: Mess Yayın, 1991.

Erdoğan, Tolga, Sinan Ünsar ve Necdet Süt, "Stresin Çalışanlar Üzerindeki Etkileri: Bir Araştırma”. Süleyman Demirel Üniversitesi İktisadi ve İdari Bilimler Fakültesi Dergisi. 14/2 (2009): 448-460.

Eren, Erol. Örgütsel Davranışve Yönetim Psikolojisi. İstanbul: Beta Basım AŞ., 2017.

Ergin, Canan. "Doktor ve Hemşirelerde Tükenmişlik ve Maslach Tükenmişlik Ölçeğinin Uyarlanması”. 11.Ulusal Psikoloji Kongresi Bilimsel Çalışmaları, 22/25 (1992): 143-154.

Erkuş, Ahmet ve Mine Afacan Fındıklı. "Psikolojik Sermayenin İş Tatmini, İş Performansı ve İşten Ayrılma Niyeti Üzerindeki Etkisine Yönelik Bir Araştırma”. İstanbul Üniversitesi İsletme Fakültesi Dergisi. 42/2 (2013): 302-319.

Eroğlu, Feyzullah. Davranış Bilimleri. İstanbul: Beta Basım AŞ. 1998. 
Erturk, Alper ve Daniel J.Inman. Piezoelectric energy harvesting. John Wiley \& Sons. 2011.

Ersezgin, Reyhan ve Emine Sevinç, Sevi Tok. "Algılanan İş Stresi, Psikolojik Dayanıklılık, Başa Çıkma Stilleri Ve Öz-Duyarlılığın Tükenmişlik Düzeyini Yordayıcı Etkisi”. Uludăg Üniversitesi Fen-Edebiyat Fakültesi Sosyal Bilimler Dergisi. 20/36 (2019): 1-36.

Esrarı, Göknur. "İş Gören Motivasyonunda Algılanan Stres Düzeyinin ve Stres Yönetim Tekniklerinin Rolü: Banka Çalışanları Üzerinde Bir Uygulama”. Atatürk Üniversitesi Sosyal Bilimler Enstitüsü Dergisi. 16/1 (2010).

González-Romá, Vicente, Wilmar B. Schaufeli, Arnold B. Bakker ve Susan Lloret. "Burnout and Work Engagement: Independent Factors or Opposite Poles". Journal Of Vocational Behavior, 68/1 (2006): 165-174.

Gillert, G. E. “The Relationshıp of Psychological Capital And Burnout With Training and Peformance". Doktora tezi, University of Oklahoma, 2014.

Göktepe, Emine Oskargil. "İşitme Engelli Çocuğa Sahip Ebeveyinlerin ÇeŞitli Psikolojik Değişkenler Açısından Değerlendirilmesi”. Yüksek Lisans Tezi, Ankara Üniversitesi, 2012.

Güçlü, Nezahat. “Zaman yönetimi”. Kuram ve Uygulamada Eğitim Yönetimi. 25/25 (2001): 93-99.

Güler, Zehra, Nuran Ö. Başpınar ve Hüseyin Gürbüz. Iş̧ Yaşamında Stres ve Kamu Kurumlarındaki Sekreterler Üzerinde Bir Uygulama. Eskişehir: Anadolu Üniversitesi Yayınları. 2001.

Güllüoğlu Özlem. "Yerel Televizyon Çalışanlarının Örgütsel Stres Faktörleri: Kayseri İlinde Bir Araştırma”. İstanbul Üniversitesi İletişim Fakültesi Dergisi. 43 (2012): 77-104.

Günay, G., Tülay Yumuk Demiralay ve Güney Çetin Gürkan. “Örgütsel İklimin İşkoliklik Üzerindeki Etkileri: Türk Zincir Otel Yöneticileri Üzerinde Bir Araştırma”. Kocaeli Üniversitesi Sosyal Bilimler Enstitüsü Dergisi. 33 (2017): 87104.

Güney, Salih. Stres ve Stresle Başa Çıkma. Ankara: Nobel Yayıncılı, 2001.

Gorgievski, M. J. ve S. E. Hobfoll. "Work can burn us out or fire us up: Conservation of resources in burnout and engagement". Handbook of stress and burnout in health care.(2008): 7-22.

Hobfoll, E. Stevan. "The İnfluence Of Culture, Community, And The Nested-Self in The Stress Process: Advancing Conservation Of Resources Theory". Applied psychology. 50/3 (2001): 337-421.

$\mathrm{Hu}$, Li-tze ve Peter M. Bentler. "Cutoff Criteria For Fit İndexes in Covariance Structure Analysis: Conventional Criteria Versus New Alternatives". Structural Equation Modeling: A Multidisciplinary Journal. 6/1 (1999): 1-55.

Qiao, Hu ve Wilmar B. Schaufeli. "The Convergent Validity of Four Burnout Measures in A Chinese Sample: A Confirmatory Factor-Analytic Approach". Applied Psychology. 60/1 (2011): 87-111. 
Jackson, Debra, Angela Firtko ve Michel Edenborough. "Personal Resilience as A Strategy For Survivingand Thriving in The Face of Workplace Adversity: A Literature Review". Journal of Advanced Nursing. 60/1 (2007): 1-9.

Karasek, Robert, Bertil Gardell ve Jan Lindell. "Work and Non-Work Correlates Of Illness And Behaviour in Male and Female Swedish White Collar Workers". Journal of Organizational Behavior. 83(1987): 187-207.

Karcıoğlu, Fatih ve Ülke H. Çelik. "Mobbing (yıldırma) ve Örgütsel Bağlılığa Etkisi”. Atatürk Üniversitesi İktisadi ve İdari Bilimler Dergisi. 26/1 (2012): 59-73.

Kaya, Çağlar ve Yahya Altınkurt. "Öğretmenlerin Psikolojik Sermayeleri İle Tükenmişlik Düzeyleri Arasındaki İlişkide Psikolojik ve Yapısal Güçlendirmenin Rolü”. Eğitim ve Bilim, 43/193 (2018): 63-74.

Kaya, Erhan. "İş Stresi ve Tükenmişlik Duygusun İşten Ayrılma Niyetine Etkileri: Sağlık Personeli Üzerinde Bir Araştırma”. Yüksek Lisans Tezi, Gebze Yüksek Teknoloji Enstitüsü, 2010.

Keskin, Gülümser. "Örgütsel Stres Ve Erzurum’da Kamu Çalışanları Üzerine Bir Uygulama”. Verimlilik Dergisi, 2 (1997): 141-164.

Kline, Paul. Handbook of Psychological Testing. London: Second Adition. 1999.

Lin, T. L. "The Relationships Among Perceived Organization Support, Psychological Capital And Employees' Job Burnout in İnternational Tourist Hotels". Life Science Journal. 10/3 (2013): 2104-2112.

Liu, Li, et al. "The Mediating Role of Psychological Capital on The Association Between Occupational Stress and Depressive Symptoms Among Chinese Physicians: A Cross-Sectional Study". BMC Public Health. 12/1 (2012): 219.

Luthans Fred, Bruce J. Avolio, James B Avey, Steven M. Norman. "Positive Psychological Capital: Measurement and Relationship With Performance and Satisfaction". Personnel Psychology. 60 (2007): 541-572.

Luthans Fred ve Carolyn M. Youssef. "Human, Socialand Now Positive Psychological Capital Management: Investing in People for Competitive Advantage". Organizational Dynamics. 33/2 (2004): 143-160.

Luthans, Fred, Kyle Luthans ve Brett Luthans. "Positive Psychological Capital: Going Beyond Human and Social Capital". Business Horizons. 47/1 (2004): 45-50.

Luthans, Fred, Carolyn M. Youssef ve Bruce J. Avolio. Psychological capital: Developing the human competitive edge. Oxford: Oxford University Press. 2007.

Macit, Mustafa. "İşkoliklik, İş - Aile Çatışması ve Tükenmişlik İliş̧kileri Üzerine Bir Araştırma”. Doktora Tezi, Gaziosmanpaşa Üniversitesi, 2015.

Maslach, Christina ve Susan E. Jackson. "The Measurement of Experienced Burnout". Journal Of Occupational Behaviour. 2 (1981): 99-113 .

Maslach, Christina, William B. Schaufeld ve Michael P. Leiter. "Job Burnout”. Annual Review Psychology. 52/1 (2001): 397-422.

Manzoni, Patrik ve Manuel Eisner. "Violence Between The Police and The Public: Influences Of Work-Related Stress, Job Satisfaction, Burnout, and Situational Factors". Criminal Justice and Behavior. 33/5 (2006): 613-645. 
Nazim, A. ve A. Ali. “The Mediating Effect of Job Satisfaction Between Psychological Capital and Job Burnout of Pakistani Nurses". Pakistan Journal of Commerce and Social Sciences. 8/2 (2014): 399-412.

Ocak, Metin ve Murat Güler. "Psikolojik Sermayenin Tükenmişlik Üzerine Etkisi: Görgül Bir Araştırma”. Erciyes Üniversitesi Iktisadi ve Idari Bilimler Faküeltesi Dergisi. 49 (2017): 121-122.

Onay, Meltem ve Sevde Kılcı. "İş Stresi ve Tükenmişlik Duygusunun İşten Ayrılma

Niyeti Üzerine Etkileri: Garsonlar ve Aşçıbaşılar”. Organizasyon ve Yönetim Bilimleri Dergisi. 3/2 (2011): 364-368.

Öncü, Ayşe. Örgüt Sosyolojisi. Ankara: Sevinç Matbaası, 1976.

Örmen, Uğur. “Tükenmişlik Duygusu ve Yöneticiler Üzerine Bir Uygulama”. Yüksek Lisans Tezi, Marmara Üniversitesi,1993.

Özen, Hasan Özgür. "Üniversite ve Devlet Hastanelerinde Çalışan Hemşirelerin Stres Düzeylerinin Karşılaştırılması: Zonguldak Örneği”. Doktora Tezi, Zonguldak Karaelmas Üniversitesi, 2011.

Özgen, Işıl. "Yiyecek-İçecek İşletmeleri Çalışanlarında Tükenmişlik Sendromu: İzmir Adnan Menderes Havalimanı Örneği”. I. Ulusal Gastronomi Sempozyumu ve Sanatsal Etkinlikler, Antalya, 4-5 Mayıs 2007.

Özkalp, Enver ve Çiğdem Kırel. Örgütsel Davranış. Bursa: Ekin Yayınevi, 2011.

Özkalp, Enver. Örgütsel Davranışta Yeni Bir Boyut: Pozitif(Olumlu) Örgütsel Davranış Yaklaşımı ve Konuları. Eskişehir: Osmangazi Üniversitesi Yayınları, 2009.

Öztürk, Veli, Seyhan Çil Koçyiğit, ve Emine Çına Bal. "Muhasebe Meslek Mensuplarının Mesleki Tükenmişlik Düzeyleri ile İşe Bağlılık Arasındaki İlişkiyi Belirlemeye Yönelik Bir Araştırma: Ankara İli Örneği”. Doğuş Üniversitesi Dergisi. 12/1 (2011): 84-98.

Özyurt, Ali. “İstanbul Hekimlerinin İş Doyumu ve Tükenmişlik Düzeyleri”. Yüksek Lisans Tezi, Marmara Üniversitesi, 2003.

Page, F. Liam ve Ross Donohue. "Positive Psychological Capital: A Preliminary Exploration Of The Construct". Monash University Department of Management Working Paper Series. 51/4 (2004): 1-10.

Pehlivan, İnayet. Yönetimde Stres Kaynakları. Ankara: Pegem A Yayıncılık, 1995.

Pelit, Elbeyi ve Fatih Türkmen. "Otel İşletmeleri İş Görenlerinin Tükenmişlik Düzeyleri: Yerli ve Yabanc1 Zincir Otel İşletmeleri İş Görenleri Üzerinde Bir Araştırma”. İktisadi ve İdari Bilimler Fakültesi Dergisi. 10/1 (2008): 117-139.

Polatcı, Sema. Kadir Ardıç ve Tinaz Z. D. “Tükenmişlik Sendromu ve Demografik Özelliklerin Tükenmişlik Üzerine Etkisi: Tokat Orta Öğretim Kurumlarında Bir Analiz". Sosyal ve Ekonomik Araştırmalar Dergisi. 7 (2007): 1-22.

Prosser, D., S. Johnson, E. Kuipers, G. Szmukler, P. Bebbington ve G. Thornicroft. "Perceived Sources of Work Stress and Satisfaction Among Hospital And Community Mental Health Staff, and Their Relation To Mental Health, Burnout And Job Satisfaction", Journal Of Psychosomatic Research. 43/1 (1997): 51-59. 
Raymond L, T. ve Blake E. Ashforth. "A Meta-Analytic Examination of The Correlates Of The Three Dimensions of Job Burnout". Journal of applied Psychology. 81/2 (1996): 123-133.

Richardson, E. Glenn. “The Metatheory of Resilienceand Resiliency”. Journal of Clinical Psychology. 58/3 (2002): 307-321.

Rowshan, Arthur. Stres Yönetimi. Çev. Ş. Cüceloğlu. İstanbul: Sistem Yayıncılık. 1998.

Sabuncuoğlu, Zeyyat ve Melek Vergiliel Tüz. Örgütsel Davranış. Bursa: Aktüel Yayınları. 2013.

Saif ur Rehman, Cao Qingren, Yasir Latif, Pervaiz Iqbal, "Impact of Psychological Capital On Occupational Burnout and Performance of Faculty Members", International Journal of Educational Management. 3/4 (2017): 455-469.

Saldamlı, Asım "Otel İşletmelerinde Stres Kaynakları ve Çalışanlar Üzerindeki Etkileri: Beş Yıldızlı Otellerde Bir Uygulama”. Çukurova Üniversitesi Sosyal Bilimler Enstitüsü Dergisi, 6/6 (2000): 291-292.

Schaufeli, B. Wilmar, Marisa Salanova, Vicente González-Romá ve Arnold B. Bakker. "The Measurement of Engagement and Burnout: A Two Sample Confirmatory Factor Analytic Approach”. Journal of Happiness Studies, 3/1(2002): 71-92.

Sefa, Bircan. "Beyoğlu Kamu Hastaneleri Birliğine Bağlı Hastanelerin Acil Servis Çalışanlarının Karşılaştığı Risk ve Tehlikelerin İş Stresine Etkisi”. Yükseklisans Tezi, Okan Üniversitesi, 2016.

Seligman, E. Martin. Authentic happiness: Using the new positive psychology to realize your potential for lasting fulfillment. New York: Simon and Schuster, 2004.

Seligman, E. Martin. "Learned Optimism: How To Change Your Mindand Your Life". American Psychologist. 55/1 (1990): 47-113.

Serinkan, C. ve İ. Arapova. "Bankacılık Sektöründe Tükenmişlik Sendromu: Kırgızistan Örneği Burnout Syndrome In Bankıng Sector: Sample Of Kyrgyzystan”. Journal of Economics. 3/5 (2018): 1-11.

Ok, Sibel. "Banka Çalışanlarının Tükenmişlik Düzeylerinin İş Doyumu, Rol Çatışması, Rol Belirsizliği ve Bazı Bireysel Özelliklere Göre İncelenmesi”. Türk Psikolojik Danışma ve Rehberlik Dergisi. 3/21 (2004): 57-59.

Soysal, Abdullah. "Farklı Sektörlerde Çalışan İşgörenlerde Örgütsel Stres Kaynakları: Kahramanmaraş ve Gaziantep’te Bir Araştırma”. Süleyman Demirel Üniversitesi İktisadi ve İdari Bilimler Fakültesi Dergisi. 14/2 (2009): 334-354.

Soygür, İ.C. ve S. Z. Aydın. "Bankacılık Sektöründe Pazarlama Ve Satış Yönlü Hedef Baskısının Banka Personeli Üzerindeki Etkisinin Analizi”. Suleyman Demirel University Journal of Faculty of Economics \& Administrative Sciences. 23/2 (2018): 341-371.

Stajkovic, D. Alexsander ve Fred Luthans. "Social Cognitive Theoryand SelfEfficacy: Going Beyond Traditional Motivationaland Behavioral Approaches". Organizational Dynamics. 26/4 (1998): 62-74.

Sucuoğlu, B. ve N. Kuloğlu. “Özürlü Çocuklarla Çalışan Öğretmenlerde Tükenmişliğin Değerlendirilmesi”. Türk Psikoloji Dergisi. 10/36 (1996): 44-60. 
Terzi, Şerife. "Üniversite Öğrencilerinin Psikolojik Dayanıklılıkları ve Algıladıkları Sosyal Destek Arasındaki İlişki”. Türk Psikolojik Danışma ve Rehberlik Dergisi. 3/29 (2016): 1-11.

Tetik, Hilmiye Türesin, Lale Oral Ataç ve Köse Sevinç. "Psikolojik Sermaye İle İş Doyumu Ve Performans İlişkisi: Türkiye'de Yapılan Araştırmalar Üzerinden Bir Meta Analizi”. Atatürk Üniversitesi İktisadi ve İdari Bilimler Dergisi. 32/2 (2018): 289-314.

Toon W. Taris, Pascale M. Le Blanc, Wilmar B. Schaufeli ve Paul J. G. Schreurs. "Are There Causal Relationships Between The Dimensions of The Maslach Burnout Inventory? A Review and Two Longitudinal Tests". Work \& Stress. 19/3 (2005): 238-255.

Topçu, M.K. ve M. Ocak. "Psikolojik Sermayenin Tükenmişlik Algısı Üzerine Etkisinde İş Tatmininin Aracılık Rolü: Türkiye ve Bosna-Hersek Sağlık Çalışanları Örneği”. Dokuz Eylül Üniversitesi Ulusal Yönetim ve Organizasyon Kongresi Bildiriler Kitabı, 2012.

Tösten, R., İ. H. Arslantaş ve G. Şahin. “Öğretmenlerin Pozitif Psikolojik Sermayelerinin Tükenmişliğe Etkisi”. Yüzüncü Yıl Üniversitesi Eğitim Fakültesi Dergisi. 14/1 (2017): 726-744.

Turunç, Ömer ve Ahmet Erkus. "Is-Aile Yasam Çatısmasının İs Tatmini Ve Örgütsel Baglilik Üzerine Etkileri: İs Stresinin Aracilik Rolü”. Selcuk Universitesi IIBF Sosyal ve Ekonomik Arastirmalar Dergisi. 13/19 (2010): 415-440.

Tutar, Hasan. İsyerinde Psikolojik Şiddet. Ankara: Platin Yayınevi. 2003.

Uygungil, Selen. "Pozitif Psikolojik Sermaye ile Çalışan Tutumları Arasındaki İlişkilerin İncelenmesi: Adana İlinde Bir Uygulama”. Doktora Tezi, Atatürk Üniversitesi, 2017.

Yang, M-H., C-T Yeh, Hung-Wen Yang ve Wui-Chiu Mu. “The İmpacts Of Perceived Organizational Support And Psychological Capital on Sport Burnout of Junior High School Physical Education Students". Life Science Journal. 10/3 (2013): 1946-1956.

Yellice Yüksel, Sema Kaner Begümhan ve Güzeller Cem. “Öğretmenlerin Mesleki Yetkinlik, Mesleki Sosyal Destek ve Tükenmişlik İlişkisinin Yapısal Eşitlik Modeli İle İncelenmesi”. Mehmet Akif Ersoy Üniversitesi Eğitim Fakültesi Dergisi. 21 (2011): 1-25.

Yim, Hee-Yun, et al. "Mediating Role Of Psychological Capital in Relationship Between Occupational Stress And Turnover İntention Among Nurses At Veterans Administration Hospitals in Korea”. Asian Nursing Research. 11/1 (2017): 6-12.

Yıldırım, M. H., E. Eylül Erul ve Kelebek Pınar. “Tükenmişlik İle İşten Ayrılma Niyeti Arasındaki İlişki Banka Çalışanları Üzerine Bir Araştırma.” Organizasyon ve Yönetim Bilimleri Dergisi. 6/1 (2014): 34-44.

Yıldız, Ebru. "Mesleki Tükenmişlik Ve Rehber Öğretmenler Üzerine Bir Araştırma”. Sakarya Üniversitesi Sosyal Bilimler Enstitüsü Dergisi. 33/2 (2012): 37-61. 
Yırık, Şevket, Deniz Ören ve Remziye Ekici. "Dört ve Beş Yıldızlı Otel İşletmelerinde Çalışan Personelin Örgütsel Stres ve Örgütsel Tükenmişlik Düzeyleri Arasındaki İşskilerin Demografik Değişkenler Bazında İncelenmesi”. Journal of Yaşar University. 9/35 (2014): 6223-6234.

Yüksel, İhsan. "İş Stresi, İşe Bağllık Ve İş Doyumu Arasındaki İlişkinin Analizi: Teknisyenlere Yönelik Bir Uygulama”. Atatürk Üniversitesi İktisadi ve İdari Bilimler Dergisi. 17/1-2 (2003): 214-224.

Yürür, Senay. "Öğrenilmiş Güçlülük, Kıdem ve Medeni Durumun Duygusal Tükenmedeki Rolü: Kaynakların Korunması Teorisi Kapsamında Bir Analiz". Atatürk Üniversitesi İktisadi ve İdari Bilimler Dergisi. 25/1 (2011): 107126.

Yom, Y. H. "Analysis of Burnout and Job Satisfaction Among Nurses Based on The Job Demand-Resource Model”. Journal of Korean Acad. Nursing. 43 (2013): 114122.

Zhang, L., J. Zhao, H. Xiao, H. Zheng, Y. Xiao, M. Chen ve D. Chen. "Mental Health And Burnout in Primary And Secondary School Teachers in The Remote Mountain Areas Of Guangdong Province in The People's Republic Of China". Neuropsychiatric Disease and Treatment. 10 (2014): 123-130. 
İNSAN\&İNSAN, Y11/Year 6, Say1/Issue 21, Yaz/Summer 2019, 493-523

DOI: https://doi.org/10.29224/insanveinsan.513475

\title{
Job Stress and Positive Psychological Capital on Burnout: A Research in the Banking Sector
}

EBRU BEYZA BAYARÇELIK / BURÇAK VATANSEVER DURMAZ / NILLAY GÜRLER

\begin{abstract}
Technological developments and intense competition increased the stress of work felt in all sectors and consequently burnout became more frequent due to the decrease of emotional resources. Despite the widespread burnout among bank employees, there are very few studies investigating the effects of positive resources combating exhaustion. The aim of this study is to examine the effects of work stress and psychological capital on burnout on public and private banks. The sample of the study consists of 300 public and private bank employees in Istanbul. Work stress scale, Maslach Burnout Scale, Psychological Resilience Scale were used to obtain the data. As a results of the analysis; while the work stress levels of the bank employees increased the level of emotional exhaustion and depersonalization which are two sub-dimensions of burnout, positive psychological capital levels of the employees decreased emotional exhaustion levels and did not affect the depersonalization.
\end{abstract}

Keywords: Work stress, Positive psychological capital, Burnout, Banking sector. 